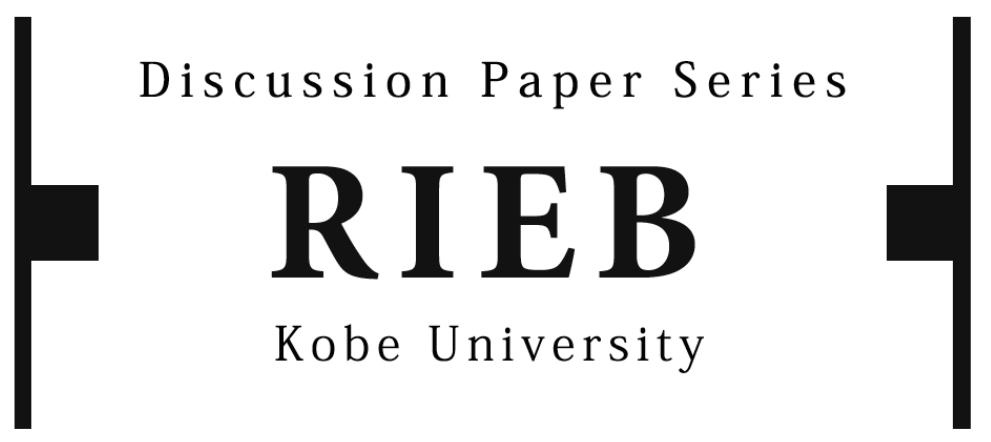

DP2020-1 1

\title{
Trade Liberalization and Wage Inequality: Evidence from Chile
}

Yoshimichi MURAKAMI

Revised July 15, 2020

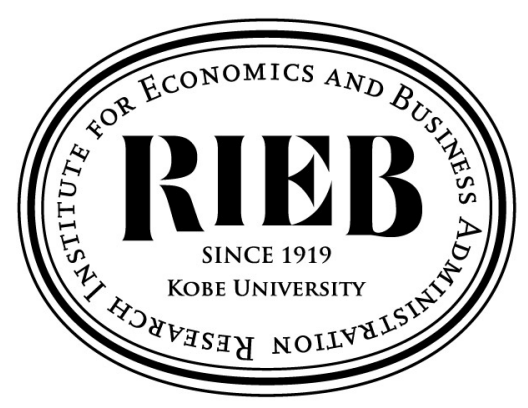

Research Institute for Economics and Business Administration Kobe University 
Revised on July 15, 2020

\section{Trade Liberalization and Wage Inequality: Evidence from Chile}

Yoshimichi Murakami*

RIEB (Research Institute for Economics and Business Administration), Kobe University, Kobe, Japan

*corresponding author

*Assistant Professor, Research Institute for Economics and Business Administration

(RIEB), Kobe University, 2-1, Rokkodai, Nada-ku, Kobe 657-8501, Japan.

Email: y-murakami@rieb.kobe-u.ac.jp 


\section{Trade Liberalization and Wage Inequality: Evidence from Chile}

This study analyzes the impacts of further tariff reductions resulting from the proliferation of regional trade agreements on wage inequality between skilled and unskilled workers in Chile in the 2000s. Thus, we use data on effective tariff rates instead of uniform most-favored-nation rates to measure trade liberalization. We match panel data on industry characteristics, including effective tariff rates, to pooled individual cross-section data from national household surveys at the industry level. We find that the reductions in effective tariffs on final goods increase industry wage premiums, thus suggesting that liberalization-induced productivity improvements lead to higher wages. However, considering the differential impacts on different skill groups, we find that the reductions significantly increase industry wage premiums only for skilled workers, thereby increasing wage inequality. Moreover, the impact is larger in skilled workers employed in large-sized firms. The results are robust to the inclusion of other industry characteristics, including input tariffs, the share of foreign-owned capital, and payments to foreign technology. The results are also robust to the inclusion of industry productivity, which is likely to affect the effective tariffs and industry wage premiums simultaneously, as well as control for the potential endogeneity of trade policy.

Keywords: regional trade agreements; effective tariffs; industry wage premiums; industry skill premiums; productivity

JEL classification codes: F16; F61; J31; O15; O54

\section{Introduction}

Over the past four decades, developing countries have implemented far-reaching trade liberalization and increasingly integrated them into the global economy, which undoubtedly has affected income distribution through several channels (Goldberg and Pavcnik 2007; Murakami 2018; Pavcnik 2017). The distributional aspect of globalization is particularly relevant for Latin American countries (LACs), not only because the region has the highest level of income inequality in the world, but also the region's inequality is often associated with poor economic growth performance due to 
political instability, including distributional conflicts, and various constraints on human capital accumulation (Bértola and Ocampo 2012). Interestingly, LACs experienced some improvement in income distribution in the 2000s after a sharp increase in income inequality in the 1980s and 1990s. Studies such as Messina and Silva (2019) and Székely and Sámano-Robles (2014) analyzed the factors underlying the recent evolution of inequality in LACs, revealing that trade liberalization is continuously one of the important factors.

Chile, considered as one of the most successful LACs in terms of economic growth and far-reaching economic reforms, is a particularly interesting case for analyzing the relationships between trade liberalization and wage inequality. In addition to continued unilateral liberalization, as typically evidenced by the application of a uniform tariff of $10 \%$ to all products except for automobiles and a few agricultural products in 1979, Chile has actively pursued regional trade agreements (RTAs) since the early 1990s (Ffrench-Davis 2010; Kuwayama 2003; Macario 2000; Zechner 2002). As a result of the enforcement of the RTAs, effective tariffs levied in each industrial sector have diverged from the uniform most-favored-nation (MFN) rates due to the preferential margins granted by the RTA scheme. This further trade liberalization, measured by effective tariffs, became especially evident in the 2000s, when free trade agreements (FTAs) with major trading partners, which have faster and comprehensive tariff elimination, including FTAs with the European Union (2003), the United States of America (2004), the Republic of Korea (2004), China (2006), and Japan (2007), came into effect. ${ }^{1}$ Indeed, effective tariffs in some industries have been nearly equal to $0 \%$ since the mid-2000s.

Some studies have tried to analyze the impacts of trade liberalization on wage inequality in Chile based on time series data and mainly focused on the period of 
unilateral liberalization in the 1970s and 1980s. However, the findings are still inconclusive and controversial. Beyer, Rojas, and Vergara (1999) find that trade openness (the ratio of exports plus imports to GDP) widened the wage inequality between skilled and unskilled workers. Murakami (2014) also finds that tariff reductions widened wage inequality. By contrast, Gallego (2012) finds that technological progress in developed counties widen wage inequality, while trade-related variables are largely insignificant. Although those studies used relatively long-term time-series data that are sourced from household surveys covering only the metropolitan area, they do not analyze the impacts of tariff reductions through RTAs in the 2000s.

Therefore, this study aims to analyze the impacts of further tariff reductions resulting from the proliferation of RTAs on wage inequality in Chile in the 2000s. This study is the first, to the best of my knowledge, to analyze the impacts of trade liberalization on wage inequality in Chile in the 2000s using panel data on industrylevel effective tariff rates and matching them to individual-level microdata from nationally representative household surveys. Tariffs have an advantage as a measure of trade liberalization because they are the most direct measures and distinguished from other indirect measures, such as trade openness, which are not necessarily consequences of trade policy changes (Rodriguez and Rodrik 2001). However, since Chile has maintained uniform MFN tariff rates, as long as they are utilized, only time series analysis using country-level data is allowed. This study overcomes this limitation by using effective tariff rates.

Several studies have analyzed the relationships between trade liberalization and wage inequality using industry-level tariffs in other LACs, including Attanasio, Goldberg, and Pavcnik (2004) for Colombia, Feliciano (2001) for Mexico, Galiani and Porto (2010) for Argentina, Goldberg and Pavcnik (2005) for Colombia, Pavcnik et al. 
(2004) for Brazil, and Paz (2014) for Colombia; they are discussed in greater detail in Section 2. However, those studies ignored the possibility that other possible channels might also affect wage inequality. Note that survey articles on the distributional aspects of globalization in developing countries such as Goldberg and Pavcnik (2007), Messina and Silva (2019), Murakami (2018), and Pavcnik (2017) revealed that there are several channels, some of which are not captured by tariffs on final goods (i.e., output tariffs). They pointed out that improved access to better foreign technologies, which usually measured by tariffs on intermediate goods (i.e., input tariffs) or more directly by the usage of foreign technologies, as well shifting some segments of production processes to third countries (i.e., within-industry offshoring), which is usually measured by foreign direct investment (FDI), are particularly important. Thus, this study confirms that our findings are robust to the inclusion of variables representing those channels such as input tariffs, FDI, and payments to foreign technology. Therefore, this study constructs industry-level panel data on those variables by the author's own calculations from plant-level microdata. Furthermore, this study also checks the robustness of the findings by the inclusion of industry productivity, which may affect both effective tariffs and workers' wages, as well as control for the potential endogeneity of effective tariffs due to a political-economic factor.

The rest of this article is organized as follows. Section 2 reviews the theoretical frameworks of globalization and wage inequality, as well as the empirical findings. Section 3 presents the empirical specifications. Section 4 explains the data employed in the analysis and presents descriptive statistics. Section 5 presents the estimation results and discusses the robustness of findings. The final section concludes the paper. 


\section{Theoretical frameworks and literature review}

This section reviews theoretical frameworks that predict the impacts of trade liberalization on wage inequality, summarizing the empirical findings in developing countries, particularly in LACs. Specifically, this study is interested in the impacts of trade liberalization through the characteristics of industries with which workers are affiliated. The wage differentials, attributable to workers' industry affiliations after controlling for other observable workers' characteristics, including educational attainments, are referred to as industry wage premiums (Galiani and Porto 2010; Goldberg and Pavcnik 2007; Pavcnik et al. 2004). Further, industry wage premiums for skilled workers (i.e., industry wage premiums that only skilled workers employed in the industry receive in addition to the base industry wage premium) are referred to as industry skill premiums (Galiani and Porto 2010; Pavcnik et al. 2004). This section reviews the theories and empirical findings regarding the impacts of trade liberalization on industry wage premiums and industry skill premiums.

Note that the standard Heckscher-Ohlin (H-O) model and its companion Stolper-Samuelson theorem predicts the impacts of tariffs on economy-wide returns rather than industry-specific returns. Thus, the standard theory that predicts the association between industry tariffs and industry wages can be the specific factors model (Attanasio, Goldberg, and Pavcnik 2004; Galiani and Porto 2010). The model assumes specific factors to be immobile across industries in the short to medium run. Thus, if the model assumes the imperfect mobility of workers employed in each industry because of the need for industry-specific skills or labor market rigidities, it predicts that workers employed in industries with larger tariff reductions will experience a larger decrease in their wages (Attanasio, Goldberg, and Pavcnik 2004; Pavcnik et al. 2004). Therefore, the model predicts a positive association between tariffs and industry 
wage premiums. ${ }^{2}$ Furthermore, if the model additionally assumes that unskilled workers are especially immobile across industries, it predicts that tariff reductions lead to a proportional decrease in the industry wage premiums for unskilled workers (i.e., an increase in industry skill premiums), thereby increasing wage inequality between skilled and unskilled workers (Pavcnik et al. 2004; Galiani and Porto 2010).

Empirical studies using household data have reported mixed results. On the one hand, some studies find the expected positive association between tariffs and industry wage premiums (e.g., Attanasio, Goldberg, and Pavcnik 2004 for Colombia; Dutta 2007 for India; Falcone and Galeano 2017 for Argentina; Ferreira, Leite, and Wai-Poi 2007 for Brazil; Galiani and Porto 2006, 2010 for Argentina; Goldberg and Pavcnik 2005 for Colombia; Kovak 2013 for Brazil; ${ }^{3}$ Paz 2014 for Colombia; and Revenga 1997 for Mexico). On the other hand, other studies find no significant association (Feliciano 2001 for Mexico; ${ }^{4}$ Pavcnik et al. 2004 for Brazil; Hasan and Jandoc 2010 for the Philippines). Moreover, others unexpectedly find a negative association (Kumar and Mishra 2008 for India). Additionally, several studies have analyzed the association between tariffs and industry skill premiums. Galiani and Porto (2006, 2010) expectedly find the negative association between tariffs and industry skill premiums in Argentina. However, Pavcnik et al. (2004) and Ferreira, Leite, and Wai-Poi (2007) find no significant association in Brazil. ${ }^{5}$

By contrast, growing literature based on models of international trade with heterogeneous firms pioneered by Melitz (2003) emphasizes that trade liberalization reallocates resources towards more productive large firms, thereby improving aggregate productivity in a given industry. Since such firms tend to utilize more advanced technologies and workers with higher skills and provide them with higher wages, trade 
liberalization induces an increase in industry wage premiums (Bernard, Redding, and Schott 2007; Yeaple 2005).

Note that the original model by Melitz (2003) defines trade liberalization as symmetric reductions in trade costs of exporting and importing. Modifying the seminal model by Melitz (2003), models by Demidova and Rodríguez-Clare $(2009,2013)$ and Felbermay, Jung, and Larch (2013) predict that even unilateral liberalization (i.e., unilateral reductions in import cost in a small economy) will also induce the productivity improvements in a given industry by forcing low productive firms to exit due to intensified import competitions and reallocating resources towards more productive firms. It is worth noting that several empirical studies (e.g., Eslava et al. 2013 for Colombia; Fernandes 2007 also for Colombia; Nataraj 2011 for India; Schor 2004 for Brazil) support the prediction that unilateral tariff reductions are indeed associated with improving industry level productivity. In addition to the import competition effect, Amiti and Konings (2007) and Topalova and Khandelwal (2011) find that improved access to better foreign technologies due to lower input tariffs also contributed to the productivity improvements. In the case of Chile, Tybout, de Melo, and Corbo (1991), Pavcnik (2002), and Bergoeing, Hernando, and Repetto (2010) find that unilateral tariff reductions increased industry productivity mainly through import competition. As discussed in the introduction, since Chile has maintained uniform tariffs across industries, even the use of data on effective tariffs do not provide sufficient cross-industry variance before $2000 .^{6}$ Thus, using alternative measures of trade liberalization such as transportation costs, Bas and Ledezma (2010) and Blyde and Iberti (2012) find that reductions in import barriers are associated with industry-level productivity improvements in Chile. 
However, only a few studies using firm-level data (e.g., Amiti and Davis 2011 for India; and Krishna, Poole, and Senses 2012 for Brazil) find that workers that employed industries with tariff reductions experienced an increase in their wages in developing countries. Moreover, they find that the increasing impacts on wages are limited to workers employed in exporting firms.

Although the original model of Melitz (2003) does not predict distributional aspects of trade liberalization, subsequent studies have developed theoretical models that incorporate the wage inequality issue into the framework of heterogeneous firms. For example, by introducing the fair wage model (Egger and Kreickemeier 2009; Amiti and Davis 2012) or search and matching frictions (Helpman, Itskhoki, and Redding 2010; Coşar, Guner, and Tybout 2016), they show that trade liberalization will increase between-firm wage inequality (i.e., wage inequality between otherwise similar workers across heterogeneous firms) because it intensifies the effect that workers employed at high-productivity large firms receive higher wages than otherwise similar workers employed at low-productivity small firms. Further, Coşar, Guner, and Tybout (2016) show that the case of unilateral tariff reductions yields the same results because the former firms, which take advantage of cheaper intermediate inputs, generate additional rents to share with their workers and pay higher wages, while the latter firms, which face greater import competition, pay lower wages. Indeed, using matched employeremployee dataset in Brazil, Krishna, Poole, and Senses (2012) empirically show that tariff reductions are associated with increasing between-firm wage inequality. Extending their previous 2009 model, Egger and Kreickemeier (2012) show that trade liberalization will increase not only between-firm wage inequality among workers with identical skills but also within-firm wage inequality among workers with different skills, thereby increasing industry skill premiums. 
Empirically, Bustos (2011) for Argentina and Linarello (2018) and Namini and López (2013) for Chile find that reductions in trading partners' tariffs expectedly increased within-firm wage inequality between skilled and unskilled workers. However, there is little evidence on the expected association between a country's own tariff reductions and within-firm wage inequality in developing countries. Some studies find no significant association between output tariffs and within-firm wage inequality (Amiti and Cameron 2012 for Indonesia; Bustos 2011 for Argentina; Caselli 2014 for Mexico; Harrison and Hanson 1999 for Mexico). Moreover, some of them (Amiti and Cameron 2012; Caselli 2014) find a positive association between input tariffs and within-firm wage inequality. ${ }^{7}$ Indeed, few empirical studies using firm (or plant) level panel data have reported that within-firm wage inequality is negatively associated with output tariffs (Furuta 2016 for India) and input tariffs (Giovannetti and Menezes-Filho 2006 for Brazil).

In summary, there are two opposite theoretical predictions: the specific factors model and the heterogeneous firm trade models. The former predicts a positive association between tariffs and industry wage premiums, while the latter predicts a negative association. Empirically, abundant literature has supported the former prediction in LACs. However, there is little supportive evidence for the latter, irrespective of the robust evidence that the import liberalization-induced productivity improvements indeed occurred at the industry level in LACs. By contrast, both models can predict that tariffs reductions increase wage inequality between skilled and unskilled workers. Although several (not many) empirical studies using household data have provided the supportive evidence in LACs, studies using firm-level data have not provided it in LACs. Additionally, the latter studies have revealed that output and input tariffs have different effects on wage inequality. 


\section{Empirical specifications}

\subsection{Trade liberalization and industry wage premiums}

The specifications of this study closely follow those proposed by Galiani and Porto (2006, 2010). The approach is to pool individual wages over time and regress them on a vector of individual characteristics (including skill levels) and a vector of industry-level characteristics (including industry tariffs) directly in one stage, which Galiani and Porto (2006) call "stronger identification strategy." Alternatively, we can estimate industry wage premiums from the wage equation separately for each year in the first stage. We then pool the industry wage premiums over time and regress them on a vector of industry-level characteristics in the second stage. Examples of the two-stage estimation strategy are Attanasio, Goldberg, and Pavcnik (2004), Feliciano (2001), Dutta (2007), Goldberg and Pavcnik (2005), Kovak (2013), Kumar and Mishra (2008), Paz (2014), and Pavcnik et al. (2004). However, the two-stage estimation strategy does not allow the inclusion of interaction terms between industry and individual characteristics in the second stage. Indeed, the heterogeneous firm literature reveals that the impacts of trade liberalization on wages can be different among the size of firms where the workers are employed (Helpman, Itskhoki, and Redding 2010). Moreover, the two-stage estimation strategy is likely to suffer from low statistical significance due to the limited sample size. ${ }^{8}$ Thus, this study employs the one-stage estimation strategy. However, to doublecheck the robustness of our results, the supplemental file presents the estimation results that employ the two-stage estimation strategy.

Although previous studies such as Amiti and Cameron (2012), Furuta (2016), and Giovannetti and Menezes-Filho (2006) find that output and input tariffs have different impacts on wage inequality, as discussed in Section 2, Galiani and Porto (2010) and the above-mentioned empirical studies employing the two-stage estimation 
strategy ignored the role of input tariffs. Thus, we also estimate the specification that includes input tariffs. Additionally, as discussed in the introduction, previous studies reveal that within-industry offshoring, usually measured by FDI (Feenstra and Hanson 1997), ${ }^{9}$ and trade-induced technological changes (Acemoglu 2003; Berman and Machin 2000) also affects wage inequality in developing countries. Note that the literature measured the trade-induced technological changes as a share of imported machinery and equipment (Acosta and Gasparini 2007; Caselli 2012; Harrison and Hanson 1999) and (or) payments to foreign technology (Harrison and Hanson 1999; Namini and López 2013). We measure the technological changes by the latter type variable. Thus, we also estimate the specification that includes the industry-level share of foreign-owned capital and payments to licenses and foreign technical assistance.

Therefore, the empirical specification for estimating the impacts of trade liberation on industry wage premiums is as follows:

$$
\ln \left(w_{i j t}\right)=\mathbf{X}_{i t}^{\prime} \boldsymbol{\beta}_{1}+\mathbf{S}_{i t}^{\prime} \boldsymbol{\beta}_{2}+\beta_{3} \ln \left(\text { outputtariff }_{j t}\right)+\beta_{4} \ln \left(\text { inputtariff }_{j t}\right)+\mathbf{Z}_{j t-1}^{\prime} \boldsymbol{\beta}_{5}+I_{j}+Y_{t}+\varepsilon_{i j t}
$$

where $i, j$, and $t$ index individual, industry, and time, respectively; $w$ is hourly wage (deflated by the national consumer price index [December $2008=1$ ]); vector $\boldsymbol{X}$ represents control variables at the individual level, which includes years of potential labor market experience (age - years of schooling - 6), its squared term, demographic dummies (a dummy each for the head of the household and married workers), informal dummy (a dummy for workers working without any kind of contract), large sized firm dummy (a dummy for workers working at firms with more than 200 people), and region dummies; vector $S$ includes dummies for two types of skilled workers (a dummy for semiskilled works (semiskilled) consisting of workers with secondary education 
graduates and dropouts and a dummy for skilled workers (skilled) consisting of college and non-college higher education graduates and dropouts); output tariff represents effective tariff rates on final goods; input tariff represents effective tariff rates on intermediate inputs; vector $\boldsymbol{Z}$ represents other industry characteristics lagged by one year to address potential endogeneity, which includes the share of foreign owned capital $(F D I)$ and the ratio of expenditure on licenses and foreign technical assistance (foreign technology); ${ }^{10} \boldsymbol{I}$ is a vector of industry effects; $\boldsymbol{Y}$ is a vector of year effects; and $\varepsilon$ is the error term.

Since previous studies find that the returns to skills captured by the vector $\boldsymbol{\beta}_{2}$ decreased substantially in the 2000s (Murakami and Nomura 2020; Parro and Reyes 2017), this study allows for the returns to skills to vary across periods; thus, interaction terms between the skill dummies and year effects are included. Additionally, following Galiani and Porto (2010), the returns to years of potential labor market experience and its squared term are also allowed to vary across periods; hence, their interactions with year effects are also included. Finally, since both the theoretical and empirical literature find a firm size-productivity premium (Berlingieri, Calligaris, and Criscuolo, 2018; Chang and van Marrewijk 2013; Fernandes 2007) and firm size-wage premium (Berlingieri, Calligaris, and Criscuolo, 2018; Helpman, Itskhoki, and Redding 2010), trade liberalization is likely to intensify the effect that large-sized firms pay higher wages. Therefore, following the estimation strategy of Fernendez (2007), this study also estimates the specification that includes an interaction term between output tariff and the large-sized firm dummy in addition to the FDI and foreign technology.

To address potential heteroscedasticity and serial correlation at the industry level in the error term, this study estimates robust standard errors clustered at the three-digit industry level. Sample weights are also used for all estimations in this study. We 
assume that the effects of common shocks or changes across all industries, such as labor-reform, exchange rates, and other macroeconomic shocks, can be captured by year effects, while time-invariant industry characteristics, which are likely to correlate with both effective tariffs and workers' wages, can be captured by the industry effects.

\subsection{Trade liberalization and industry skill premiums}

As explained in Section 2, in addition to the base industry wage premiums, skilled workers are likely to receive additional wage premiums according to their industry affiliation. Thus, we estimate the impacts of trade liberalization on industry skill premiums by adding interaction terms between the effective tariffs (output tariff and input tariff) and the skill dummies $\boldsymbol{S}$, as well as interaction terms between industry characteristics $\boldsymbol{Z}$, consisting of FDI and foreign technology, and the skill dummies $\boldsymbol{S}$, to equation (1). The empirical specification is as follows:

$$
\begin{aligned}
\ln \left(w_{i j t}\right)= & \mathbf{X}_{i t}^{\prime} \boldsymbol{\beta}_{1}+\mathbf{S}_{i t}^{\prime} \boldsymbol{\beta}_{2}+\beta_{3} \ln \left(\text { outputtariff }_{j t}\right)+\beta_{4} \ln \left(\text { inputtariff }_{j t}\right)+\ln \left(\text { outputtariff }_{j t}\right) * \mathbf{S}_{i t}^{\prime} \boldsymbol{\beta}_{5} \\
& +\ln \left(\text { inputtariff }_{j t}\right) * \mathbf{S}_{i t}^{\prime} \boldsymbol{\beta}_{6}+\mathbf{Z}_{j t-1}^{\prime} \boldsymbol{\beta}_{7}+\mathbf{Z}_{j t-1} * \mathbf{S}_{i t}^{\prime} \boldsymbol{\beta}_{8}+I_{j}+Y_{t}+\varepsilon_{i j t}
\end{aligned}
$$

where variables are the same as in equation (1). We also estimate the specification that includes the interaction terms between the output tariffs, interacted with the skill dummies, and large-sized firm dummy. Other variables and estimation strategies are the same as equation (1).

\section{Data and descriptive statistics}

\subsection{Individual-level data}

The data on wages and individual characteristics are sourced from Encuesta de 
Caracterización Socioeconómica Nacional (Socio-economic Characterization Survey,

CASEN) for 2000, 2003, 2006, and 2009. ${ }^{11}$ CASEN is a nationally representative crosssectional household survey conducted every two or three years by the Ministry of Social Development and Family of Chile (former the Ministry of Social Development and the Ministry of Planning and Cooperation). CASEN provides detailed information on demographic characteristics, education, health, housing, employment, and various sources of income. Further, a favorable feature of this survey for this study is that the surveys report a worker's industry affiliation at the four-digit level of international standard industrial classification (ISIC). Thus, this study pools the individual data from the surveys and matches them with panel data on industry characteristics at the ISIC classification. This study limits the sample to male workers who are employed full-time (more than 40 hours per week) in manufacturing sectors and are aged between 14 to 65 years, excluding self-employed workers and military personnel.

Table 1 reports the descriptive statistics. We find that the share of semiskilled workers slightly increased from 2000 to 2009, while the shares of unskilled (defined as those having, at most, a complete primary education) and skilled workers slightly decreased in this period.

[Insert Table 1 near here]

\subsection{Industry-level data}

Although this study uses effective tariff rates as the measure of trade liberalization, there are some difficulties in calculating them. This difficulty is because effective tariff rates are not necessarily immediately equal to 0 on all products after the enforcement of RTAs due to the exceptions to tariff reductions and eliminations. ${ }^{12}$ However, some attempts have certainly been made. Bergoeing, Hernando, and Repetto (2006) 
calculated import-weighted average effective tariffs in Chile for the period from 1980 to 2001. Becerra (2006) calculated them at the industry-level for the period from 2000 to 2005. Thus, subsequent studies such as Cavallo (2008), Valdés and Jara (2008), Bergoeing, Hernando, and Repetto (2010), and Álvarez and Fuentes (2018) used these calculations for their empirical analysis. Regarding the period after 2006, the frequently used database of the World Integrated Trade Solution (WITS) also provides reliable data. ${ }^{13}$ Thus, following the estimation strategy of those studies, this study sources the data for the output tariffs from Becerra (2006) for the years 2000 and 2003, and the WITS database for the years 2006 and 2009. We also need to note that Becerra (2006) do not classify all industries by the three-digit level of ISIC (revision 2); some sectors are classified according to the two-digit level, and others are classified according to the aggregated three-digit level (i.e., some three-digit level sectors are aggregated into one sector). Thus, although this study maintains the three-digit level classification for all periods under analysis, we consider effective tariff rates of such aggregated sectors as identical at the three-digit level. ${ }^{14}$

Following Amiti and Cameron (2012), we construct the input tariffs by weighting the output tariffs by the industry's input cost shares, as follows:

$$
\text { inputtariff }_{j t}=\sum_{k} \alpha_{j k} \cdot \text { outputtariff }{ }_{k t} \text {, }
$$

where $\alpha_{j k}$ is the share of input of industry $k$ purchased by industry $j$. The share of input, based on the total input purchases, including domestic and imported inputs, is calculated by coefficients of the input-output table of Chile in $2003 .{ }^{15}$

Table 1 also shows the industry-related descriptive statistics. The average effective tariff rates in manufacturing sectors decreased from $7.8 \%$ in 2000 , which is slightly below the MFN tariff rates (9\%), to $3.4 \%$ in 2003, $2.3 \%$ in 2006 , and $1.6 \%$ in 
2009, which are substantially below the MFN tariff rates (6\%) in those years. The reduction and divergence from the MFN tariff rates reflect that major FTAs with faster and comprehensive tariff elimination came into effect in the period, and the tariff elimination periods of major Economic Complementation Agreements (ECAs) (usually around 10 years) expired.

The other two industry characteristics (FDI and foreign technology) are calculated from plant-level data from Encuesta Nacional Industrial Anual (Annual Survey of Manufacturing Industries, ENIA). ${ }^{16}$ The survey, which is carried out by the National Institute of Statistics of Chile, covers all manufacturing plants with more than 10 employees and provides plant-level detailed information on sales, employment, wages, input material and service expenditures, and fixed assets (see the Appendix). Following the FDI studies (e.g., Javorcik 2004), we measure the industry-level FDI by the share of foreign-owned capital averaged over all plants, weighted by each plant's share in sectoral sales. Since the share of foreign capital has significant regional variation in Chile, the sectoral sales are calculated at the region-industry level. Similarly, we measure industry-level foreign technology by the ratio of expenditure on licenses and foreign technical assistance to total sales averaged over all plants, weighted by each plant's share in the industry sales. We find that the share of foreign capital and the ratio of expenditure on licenses and foreign technical assistance slightly decreased from 2000 to 2009.

\section{Estimation results}

\subsection{Trade liberalization and industry wage premiums}

Table 2 reports the estimation results of equation (1). We find that, in all specifications, the coefficient of output tariffs is negative and significant, indicating that reductions in 
output tariffs are associated with increasing industry wage premiums. The coefficients of foreign technology are positive and significant, as expected. In contrast, the coefficients of input tariffs and FDI are insignificant, and their inclusion does not affect the sign, magnitude, and significance of output tariffs. The coefficient of output tariffs interacted with a large-sized firm dummy is expectedly negative but insignificant. Therefore, the findings indicate that productivity improvements induced through foreign competitions lead to higher workers' wages in Chile. Although the findings are consistent with Kumar and Mishra (2008) for India, they are in contrast with previous studies analyzing other LACs, such as Attanasio, Goldberg, and Pavcnik (2004) for Colombia, Galiani, and Porto (2010) for Argentina, Goldberg and Pavcnik (2005) for Colombia, Kovak (2013) for Brazil, and Paz (2014) for Colombia, who found a positive association between tariffs and industry wage premiums and, thus, supported the prediction of specific factors model, as discussed in Section 2. Thus, this study provides new evidence for the impacts of trade liberalization on industry wage. We also find that the coefficients of the interaction terms between skilled workers dummies and year effects, especially year effect of 2009 , are negative, confirming a decrease in economywide returns to skilled workers in the 2000s, as Murakami and Nomura (2020) and Parro and Reyes (2017) also find.

[Insert Table 2 near here]

\subsection{Trade liberalization and industry skill premiums}

Table 3 reports the estimation results of equation (2). Note that we do not repeat the estimation results of the coefficients of skilled dummies (including their interactions with year effects) in the subsequent tables. We find the higher the skill category, the larger (in absolute value) coefficient of output tariffs; moreover, the coefficient of 
output tariffs is significant only for the interaction with semiskilled and skilled workers. Therefore, we find that reductions in output tariffs lead to increases in industry skill premiums and, thus, wage inequality between skilled and unskilled workers. The finding is consistent with Galiani and Porto (2006; 2010) for Argentina and Krishna, Poole, and Senses (2012) for Brazil. Interestingly, this study also finds that the coefficient of output tariffs is significantly larger (in absolute value) for skilled workers employed in large-sized firms. Therefore, the findings are precisely consistent with the predictions of heterogeneous firm trade models: productivity improvements due to intensified foreign competitions are associated with increasing industry wage premiums; however, the increasing effects on wages are biased towards favoring skilled workers, especially those employed in large-sized firms.

We also find that the coefficient of FDI is positive and significant only for the interaction with skilled workers, indicating that an increase in FDI leads to increasing industry skill premiums and wage inequality between skilled and unskilled workers. The finding is consistent with recent empirical studies analyzing LACs, including Herzer et al. (2014), Kristjanpoller and Contreras (2017), Murakami and Hamaguchi (2017), and Suanes (2016). By contrast, the coefficients of input tariffs and foreign technology, including their interactions with skilled dummies, are insignificant, thus suggesting that foreign technologies may not be skill-biased in this period in Chile. Importantly, we confirm that the inclusion of input tariffs, FDI, and foreign technology, including their interactions with skilled dummies, do not affect the sign, magnitude, and significance of output tariffs.

[Insert Table 3 near here] 


\subsection{Robustness check}

A possible concern with the findings is the potential endogeneity of effective tariffs to wages. Thus, to ameliorate the endogeneity problem, many control variables such as the time-varying returns to skills and labor market experience, the detailed individual characteristics, the industry effects, and the year effects are included in our empirical specification, as discussed in Sections 3 and 4. However, to check the robustness of the findings, we perform two additional exercises.

First, the heterogeneous firm trade models predict that the key factor affecting workers' wages is the productivity of the firm or industry in which they are employed. However, productivity is also likely to be correlated with tariffs (Schor 2004; Paz 2014). This likelihood is because tariff reductions are considered to improve industrylevel productivity, as discussed in Section 2. Moreover, this negative correlation between industry-level tariffs and productivity can also be derived from a politicaleconomic factor because low productivity industries are likely to pressure the government for higher tariffs to maintain the protection from foreign competitions (Schor 2004). This factor is especially crucial for this study because effective tariff rates, which are our measure of trade liberalization instead of nominal MFN tariff rates, are determined by the exceptions to tariff reductions and eliminations in RTAs, as well as the choice of partners with which the country has RTAs. Thus, this process is likely to allow much room for political lobbying. Therefore, for those two reasons, effective tariffs are considered to be negatively associated with productivity.

Figure 1 shows the relationships between effective tariff rates and productivity at the three-digit ISIC level in 2000. We estimate the plant-level Levinsohn-Petrin total factor productivity (TFP) (Levinsohn and Petrin 2003) using the data from ENIA (for details, see the Appendix). We calculate the industry-level weighted average of TFP 
using each plant's share in the industry sales as the weights. Interestingly, we find the expected negative relationships between effective tariffs and TFP at the industry-level; that is, low productivity industries indeed tend to have higher effective tariffs. Thus, since industry-level productivity is considered to be positively correlated with workers' wages, the omission of productivity results in the overestimation of the coefficient of output tariffs in absolute value.

\section{[Insert Figure 1 near here]}

Therefore, following Paz (2014), we estimate equations (1) and (2) by adding industry-level TFP. Tables 4 and 5 show the estimation results. As expected, we find that the coefficient of TFP is positive (though it is weakly significant). Thus, the coefficient of output tariffs was indeed slightly overestimated in absolute value in the previous estimation without the inclusion of TFP: the previous estimation shows that a $1 \%$ reduction in output tariffs leads to a $0.134 \%$ increase in industry wage premium (Column (1) of Table 2), while the re-estimation with the inclusion of TFP shows that it leads to a $0.131 \%$ increase in industry wage premium (Column (1) of Table 4$).{ }^{17}$ However, the inclusion of TFP does not affect the baseline results: reductions in output tariffs lead to an increase in average industry wage premiums; however, considering the differential impacts of reductions in output tariffs on different skill groups, they lead to an increase in industry wage premiums for only skilled workers, and the effect is significantly larger for those employed in large-sized firms. Moreover, the findings are robust when controlling for input tariffs, FDI, and foreign technology.

[Insert Tables 4 and 5 near here]

However, unobservable time-varying industry characteristics may be still correlated to both workers' wages and effective tariffs after controlling for industry- 
level productivity. For example, industries with powerful unions, which are more likely to lobby the government for protection, are considered to have higher tariffs. Moreover, workers employed in such industries are likely to receive higher wages because those industries can extract some industry rents associated with protection (Galiani and Porto 2010). Therefore, the omission of such time-varying political characteristics results in the underestimation of the coefficient of output tariffs in absolute value.

To address this concern, following Attanasio, Goldberg, and Pavcnik (2004), Kumar and Mishra (2008), and Pavcnik et al. (2004), we apply an instrumental variables strategy. An ideal instrument should be highly correlated with effective tariffs but uncorrelated to the industry-specific time-varying unobservable component of wages (Kumar and Mishra 2008). Although it is difficult to find such an ideal instrument, this study argues that the MFN tariff rate in each year interacted with initial applied tariff levels (in 2000) is an appropriate instrument. This argument is because the MFN tariff rate in each year is completely flat across industries in Chile; thus, it is exogenously determined. Moreover, both applied tariffs and MFN tariffs show a decreasing trend from 2000 to 2009. Furthermore, the initial tariff levels are closely related to the cross-industry patterns of the subsequent tariff levels. Note that Attanasio, Goldberg, and Pavcnik (2004), Goldberg and Pavcnik (2005), and Pavcnik et al. (2004) used the exchange rate and coffee price in each year interacted with initial tariff levels as the instruments. However, the evolution of the exchange rate and coffee prices across the years do not necessarily link to that of tariff levels. Since the MFN tariff levels always link to applied tariff levels, our proposed instrument is obviously more appropriate in the case of Chile. Regarding the interaction terms, we use the original instrument interacted with the explanatory variables in question (e.g., we use the original instrument interacted with skilled dummies as the instrument for the output 
tariffs interacted with skilled dummies). Note that we do not include input tariffs in the estimation using the instruments because the variable is already found to be insignificant.

Table 6 presents the estimation results using instrumental variables. The DurbinWu-Hausman test strongly rejects the null hypothesis of exogeneity of output tariffs. Given that the Kleibergen-Paap rank F statistics are larger than the Stock-Yogo weak ID test critical value (see specifications (1) to (3) of Table 6), we reject the null hypothesis that the instrument is a weak instrument. Interestingly, if we estimate the residual from the first stage regression, which captures the endogenous components of effective tariffs, we find the expected positive relationships between effective tariff rates and the residual (see Figure 2). Thus, we find that the coefficient of output tariffs was substantially underestimated in absolute value in the estimation without using the instrument: the estimation shows that a $1 \%$ reduction in output tariffs leads to a $0.131 \%$ increase in industry wage premiums (Column (1) of Table 4), while the estimation using the instrument shows that it leads to a $0.450 \%$ increase in industry wage premiums (Column (1) of Table 6). Therefore, we find that the impacts of output tariffs on wage inequality are more important and practically large when we appropriately address the endogeneity of effective tariffs. Note that in the estimation using the instrument, we find that the coefficients of output tariffs are also significant for unskilled workers. However, skilled workers still receive additional industry wage premiums for them. For example, Column (5) of Table 6 shows that a 1\% reduction in output tariffs leads to a $0.222 \%$ increase in industry wage premiums for unskilled workers, while it leads to a $0.439 \%$ increase in those for skilled workers. That is, reductions in output tariffs lead to a larger increase in industry wage premiums for skilled workers than unskilled workers, thereby increasing wage inequality between them. Thus, we find that the baseline 
results remain unchanged when using the instrument. We again confirm that the inclusion of FDI and foreign technology does not affect the sign, magnitude, and significance of output tariffs.

\author{
[Insert Figure 2 near here] \\ [Insert Table 6 near here]
}

\title{
6. Concluding remarks
}

This study analyzed the impacts of further tariff reductions resulting from the proliferation of RTAs on the wage inequality between skilled and unskilled workers in Chile in the 2000s. For this purpose, we used data on effective tariff rates instead of uniform most-favored-nation rates as the trade liberalization measure. Furthermore, to control for other possible channels through which globalization would affect wage inequality, we constructed industry-level panel data on the variables representing those channels such as FDI, payments to foreign technology, and productivity based on the author's own calculations from plant-level microdata. Matching those panel data to pooled individual cross-section data from nationally representative household surveys at the industry level, this study estimated the impacts of trade liberalization on workers' wages directly in one stage. To the best of my knowledge, this is the first study to analyze the impacts of effective tariffs on wage inequality in Chile using detailed household and plant-level data.

We found that the reductions in output tariffs increased industry wage premiums, thus suggesting that liberalization-induced productivity improvements led to higher industry wages. However, considering the differential impacts of output tariffs on different skill groups, we found that the reductions significantly increased industry wage premiums for only skilled workers, thereby increasing wage inequality between 
skilled and unskilled workers. Moreover, the impact of output tariffs on industry skill premiums is significantly larger for skilled workers employed in large-sized firms. Therefore, the findings are exactly consistent with the predictions of heterogeneous firm trade models: productivity improvements due to intensified foreign competitions are associated with increasing industry wage premiums; however, the increasing effects on wages are biased towards favoring skilled workers, especially those employed in largesized firms. By contrast, the findings of previous studies analyzing LACs largely supported the predictions of the specific factors model: tariff reductions decreased industry wage premiums, while they increased wage inequality between skilled and unskilled workers. Therefore, the findings provide new evidence related to trade liberalization and inequality in LACs, which is a novel contribution of this study to the literature.

This study found that FDI had similar impacts on wage inequality in Chile: FDI was associated with increasing industry wage premiums, while it was particularly associated with those for skilled workers, thereby increasing wage inequality, which supports the findings of previous studies analyzing LACs. By contrast, we found that input tariffs and payments to foreign technology, which are variables related to the improved access to foreign technology and its usage, did not affect wage inequality between skilled and unskilled workers.

This study also made a novel contribution to the literature by carefully showing the robustness of the impacts of output tariffs on wage inequality. First, we showed that the impacts were robust to the inclusion of input tariffs, FDI, and the payments to foreign technology, which representative studies analyzing the links between tariffs and wage inequality in LACs such as Attanasio, Goldberg, and Pavcnik (2004), Galiani and Porto (2010), Goldberg and Pavcnik (2005), Pavcnik et al. (2004), and Paz (2014) 
ignored. Second, following Paz (2014), we showed that impacts were also robust to the inclusion of industry productivity, which affected effective tariffs and industry wage premiums simultaneously, thereby finding that its omission led to biased estimates of effective tariffs. Finally, using instrumental variables, we verified the robustness of the results by controlling for the potential endogeneity of effective tariffs due to a politicaleconomic factor: although the baseline results remain unchanged, the impacts of output tariffs on wage inequality became more important if appropriately addressing the endogeneity of effective tariffs.

The finding that trade liberalization still operated in the direction of increasing wage inequality in Chile in the 2000s may require further research. First, considering the observed decrease in wage inequality in this period, the finding may be puzzling. However, this decrease can be attributed to supply-side factors such as an increase in more educated workers due to the expansion of higher education, as pointed out by Murakami and Nomura (2020). Thus, further research on the economic factors explaining the decrease in wage inequality in this period, considering both demand and supply factors, may be required. Second, to reveal the distributional effects of trade liberalization entirely, we require a detailed analysis of the effects on household welfare across different income groups, especially based on the estimation of tariff pass-through on domestic prices (for example, see Casabianca 2016 for Paraguay; Porto 2006 for Argentina; Finot, LaFleur and Durán 2011 for Chile). Such an analysis is beyond the scope of this study; however, especially from a policy perspective, it may be an interesting subject for future research.

\section{Acknowledgments}

The author is grateful to Manabu Furuta, Yasuhiro Gintani, Nobuaki Hamaguchi, Isao Kamata, Hiroyuki Nishiyama, and Takahiro Sato for their insightful comments and constructive 
suggestions. The author is also grateful to Seiji Horii, Masahiro Ikeda, Kouta Ito, Hiroyuki Mizuno for assisting the research. Note that some ideas and methodologies of this article are based upon the author's discussion paper "Trade policy and wage inequality in Chile since the 1990s," (Documentos de Proyectos 518, The United Nations Economic Commission for Latin America and the Caribbean (ECLAC)). Thus, the author's thanks also go to José Durán, Sebastián Faúndez, Hernán Frigollett, Atsushi Fukumi, Yoshiaki Hisamatsu, Ekaterina Krivonos, Kyosuke Kurita, Mikio Kuwayama, Xavier Mancero, Yukitoshi Matsushita, the late Shoji Nishijima, Tomokazu Nomura, Andrea Pellandra, and Setsuko Yukawa for their insightful comments and constructive suggestions in this stage. This study was substantially developed from the discussion paper, incorporating new theoretical frameworks and literature review, dataset, and methodologies. Any remaining errors are the author's own.

\section{Declaration of interest statement}

There are no potential conflicts of interest to declare.

\section{Funding}

This work was supported by the [JSPS KAKENHI] under Grant [Number 17K17877]. 


\section{Notes}

1. Most of the RTAs that came into effect during the 1990s fall into a category known as Economic Complementation Agreements (ECAs), which focus on the elimination of tariffs and non-tariff barriers for goods. The representative examples are ECAs with Mexico (1992), Venezuela (1993), Bolivia (1993), Colombia (1994), Ecuador (1995), and Peru (1998). By contrast, FTAs not only have faster and more comprehensive tariff elimination but also include those areas not addressed by ECAs, such as investment, trade in services, competition policy, government procurement, and intellectual property rights. For more details, see Kuwayama (2003).

2. Note that the model that incorporates non-competitive wage-setting mechanisms such as labor union into simple the $\mathrm{H}-\mathrm{O}$ model also provides a positive association between tariffs and industry wage premiums because tariff reductions are likely to decrease the industry rents. For more details, see Galiani and Porto (2010).

3. Kovak (2013) estimates wage premiums at the region instead of the industry level.

4. Feliciano (2001) finds a positive association between import licenses and industry wage premiums.

5. Using export shares instead of tariffs, Brambilla et al. (2011) find that the variable increased industry skill premiums in 16 LACs.

6. Thus, Pavcnik (2002) assumes that the impacts of uniform tariffs can be captured by the year indicators.

7. Amiti and Cameron (2012) argue that the finding is not surprising because reductions in input tariffs induced firms to switch from producing high-skilled intensive intermediate inputs to importing them, thereby reducing relative demand for skilled workers.

8. Even classified according to the three-digit ISIC level, the number of industries is only 29.

9. Since offshoring usually involves FDI, except for the case of foreign outsourcing, which is very difficult to measure, the impacts of offshoring are usually assessed by using FDI (Khalifa and Mengova 2010).

10. Due to the data availability, the variables are lagged by two years in the year 2009. Due to the classification change of industry affiliation from ISIC revision 2 to 3 in 2008, ENIA for 2007 provides the last available data classified at ISIC revision 2.

11. We sourced the data from http://observatorio.ministeriodesarrollosocial.gob.cl/casenmultidimensional/casen/basedatos.php (accessed on June 6, 2018).

12. For the list of the exceptions to tariff reductions in RTAs, see Agosin (1999) and Table Annex 1-A of Schuschny et al. (2007: 101).

13. Although the share of imports from countries with which Chile has RTAs to the total 
imports was exceeded in 1996 and continuously increased since then (Dúran 2008), the effective tariff rates until 2003 that WITS provides are almost homogenous and identical to MFN tariff rates. Thus, the data in this period, apparently, do not reflect the realities and are not reliable.

14. For example, since Becerra (2006) aggregate ISIC 381, 383, and 385 into one sector, we consider effective tariff rates of those sectors as identical.

15. Thus, we assume that the share of input is constant over the period under the analysis. We sourced the data from https://si3.bcentral.cl/estadisticas/Principal1/Excel/CCNN/cdr/excel.html (accessed on January 27, 2019).

16. We sourced the data from

http://historico.ine.cl/canales/chile_estadistico/estadisticas_economicas/industria/series_estadist icas/series_estadisticas_enia.php (accessed on April 14, 2016).

17. However, the overestimation is substantially smaller than that of Paz (2014) for Colombia, who finds that the inclusion of TFP decreases the tariff coefficient by almost $40 \%$.

\section{References}

Acemoglu, D. 2003. Patterns of skill premia. Review of Economic Studies 70, no. 2: 199-230.

Acosta, P., and L. Gasparini. 2007. Capital accumulation, trade liberalization, and rising wage inequality: The case of Argentina. Economic Development and Cultural Change 55: 793-812.

Agosin, M. 1999. Chile: Comercio y crecimiento: realizaciones del pasado y perspectivas para el futuro. in CEPAL, Nuevas políticas comerciales en América Latina y Asia: Algunos casos nacionales. Santiago: CEPAL, 205-270.

Álvarez, R., and R. Fuentes. 2018. Minimum wage and productivity: Evidence from Chilean manufacturing plants. Economic Development and Cultural Change 67, no. 1: 193-223.

Amiti, M., and L. Cameron. 2012. Trade liberalization and the wage skill premium: Evidence from Indonesia. Journal of International Economics 87: 277-87.

Amiti, M., and D.R. Davis. 2011. Trade, firms, and wages: Theory and evidence. Review of Economic Studies 79: 1-36.

Amiti, M., and J. Konings. 2007. Trade liberalization, intermediate inputs, and productivity: Evidence from Indonesia. American Economic Review 97, no. 5: 1611-38. 
Attanasio, O., P.K.Goldberg, and N. Pavcnik. 2004. Trade reforms and wage inequality in Colombia. Journal of Development Economics 74, no. 2: 331-66.

Bértola, L., and J.A. Ocampo. 2012. The economic development of Latin America since independence. Oxford, UK: Oxford University Press.

Brambilla, I., R. Dix-Carneiro, D. Lederman, and G. Porto. 2011. Skills, exports, and the wages of seven million Latin American workers. World Bank Economic Review 26, no. 1: 34-60.

Bas, M., and I. Ledezma. 2010. Trade integration and within-plant productivity evolution in Chile. Review of World Economics 146, no. 1: 113-46.

Becerra, G. 2006. “Arancel efectivo de las importaciones chilenas 2000-2005,” Estudios Económicos Estadísticos, 50, Santiago: Banco Central de Chile.

Bergoeing, R., A. Hernando, and A. Repetto. 2006. Market reforms and efficiency gains in Chile. Working Paper 372, Central Bank of Chile, Santiago.

Bergoeing, R., A. Hernando, and A. Repetto. 2010. Market reforms and efficiency gains in Chile. Estudios de Economica 37, no. 2: 217-42.

Berlingieri, G., S. Calligaris, and C. Criscuolo. 2018. The Productivity-Wage Premium: Does Size Still Matter in a Service Economy? AEA Papers and Proceedings 108: $328-33$.

Berman, E., and S. Machin. 2000. Skill-biased technology transfer around the world. Oxford Review of Economic Policy 16, no. 3: 12-22.

Bernard, A.B., S.J. Redding, and P.K. Schott. 2007. Comparative advantage and heterogeneous firms. Review of Economic Studies 74: 31-66.

Beyer, H., P. Rojas, and R. Vergara. 1999. Trade liberalization and wage inequality. Journal of Development Economics 59, no. 1: 103-23.

Blyde, J. and G. Iberti. 2012. Trade costs, resource reallocation and productivity in developing countries. Review of International Economics 20, no. 5: 909-23.

Bustos, P. 2011. The impact of trade liberalization on skill upgrading. Evidence from Argentina. Working Paper 1189, Department of Economics and Business, Universitat Pompeu Fabra.

Casabianca, E.J. 2016. Distributional effects of multilateral and preferential trade liberalisation: The case of Paraguay. Journal of International Trade \& Economic Development 25, no. 1: 80-112. 
Caselli, M. 2014. Trade, skill-biased technical change and wages in Mexican manufacturing. Applied Economics 46, no. 3: 336-48.

Cavallo, E. A. 2008. Output volatility and openness to trade: A reassessment. Economía 9, no. 1: $105-52$.

Chang, H.H., and C. Van Marrewijk. 2013. Firm heterogeneity and development: Evidence from Latin American countries. Journal of International Trade \& Economic Development 22, no. 1: 11-52.

Coşar, A. K., N. Guner, and J. Tybout. 2016. Firm dynamics, job turnover, and wage distributions in an open economy. American Economic Review 106, no. 3: 62563.

Demidova, S. and A. Rodriguez-Clare. 2009. Trade policy under firm-level heterogeneity in a small economy. Journal of International Economics 78: 10012.

Demidova, S. and A. Rodriguez-Clare. 2013. The simple analytics of the Melitz model in a small economy. Journal of International Economics 90: 266-72.

Dúran, J. 2008. Indicadores de comercio exterior y política comercial generalidades metodológicas e indicadores básicos, Santiago: CEPAL.

Dutta, P.V. 2007. Trade protection and industry wages in India. Industrial and Labor Relations Review 60, no. 2: 268-86.

Egger, H., and U. Kreickemeier. 2009. Firm heterogeneity and the labor market effects on trade liberalization. International Economic Review 50, no. 1: 187-216.

Egger, H., and U. Kreickemeier. 2012. Fairness, trade, and inequality. Journal of International Economics 86: 184-96.

Eslava, M., J. Haltiwanger, A. Kugler, and M. Kugler. 2013. Trade and market selection: Evidence from manufacturing plants in Colombia. Review of Economic Dynamics 16: 135-58.

Falcone, G., and L. Galeano. 2017. Trade reforms and industry wage premium: Evidence from Argentina. Documento de Trabajo 212, Centro de Estudios Distributivos, Laborales y Sociales, Universidad Nacional de la Plata.

Feenstra, R.C., and G.H. Hanson. 1997. Foreign direct investment and relative wages: Evidence from Mexico's maquiladoras. Journal of International Economics 42, no. 3: 371-93. 
Felbermayr, G., B. Jung, and M. Larch. 2013. Optimal tariffs, retaliation, and the welfare loss from tariff wars in the Melitz model. Journal of International Economics 89: 13-25.

Feliciano, Z.M. 2001. Workers and trade liberalization: The impact of trade reforms in Mexico on wages and employment. ILR Review 55, no. 1: 95-115.

Fernandes, A.M. 2007. Trade policy, trade volumes and plant-level productivity in Colombian manufacturing industries. Journal of International Economics 71: $52-71$.

Ferreira, F.H.G., P.G. Leite, and M. Wai-Poi. 2007. Trade liberalization, employment flows and wage inequality in Brazil. World Bank Policy Research Working Paper 4108, World Bank.

Ffrench-Davis, R. 2010. Economic Reforms in Chile: From Dictatorship to Democracy, New York: Palgrave Macmillan.

Finot, A., M. LaFleur, and J. Dúran. 2011. Analysis of the effects of trade opening on household welfare: An application to Chile, 1999-2006. In Trade, poverty and complementary policies in Latin America, ed. J. Dúran, M. Lafleur, and A. Pellandra, 249-73, Santiago, Chile: Economic Commision for Latin America and the Caribbean.

Furuta, M. 2016. Trade liberalization and wage inequality in the Indian manufacturing sector. MPRA Paper 73709, Munich Personal RePEc Archive.

Galiani, S., and G. Porto. 2006. Trends in tariff reforms and trends in wage inequality. World Bank Policy Research Working Paper 3905, World Bank.

Galiani, S., and G. Porto. 2010. Trends in tariff reforms and trends in the structure of wages. Review of Economics and Statistics 92, no. 3: 482-94.

Gallego, F.A. 2012. Skill premium in Chile: Studying skill upgrading in the South. World Development 40, no. 3: 594-609.

Giovannetti, B., and Menezes-Filho. N. 2006. Trade liberalization and the demand for skilled labor in Brazil. Economía 7, no. 1: 1-28.

Goldberg, P.K. and N. Pavcnik. 2005. Trade, wages, and the political economy of trade protection: evidence from the Colombian trade reforms. Journal of International Economics 66: 75- 105.

Goldberg, P.K. and N. Pavcnik. 2007. Distributional effects of globalization in developing countries. Journal of Economic Literature 45, no. 1: 39-82. 
Harrison, A., and G. Hanson 1999. Who gains from trade reform? Some remaining puzzles. Journal of Development Economics 59: 125-54.

Hasan, R., and K.R.L. Jandoc. 2010. Trade liberalization and wage inequality in the Philippines. ADB Economics Working Paper 195, Asian Development Bank.

Helpman, E., O. Itskhoki, and S. Redding. 2010. Inequality and unemployment in a global economy. Econometrica 78, no. 4: 1239-83.

Herzer, D., P. Hühne, and P. Nunnenkamp. 2014. FDI and income inequality: Evidence from Latin American economies. Review of Development Economics 18, no. 4: 778-93.

Javorcik, B.S. 2004. Does foreign direct investment increase the productivity of domestic firms? In search of spillovers through backward linkages. American Economic Review 94, no. 3: 605-27.

Kovak, B.K. 2013. Regional effects of trade reform: What is the correct measure of liberalization? American Economic Review 103, no. 5: 1960-76.

Khalifa, S., and E. Mengova. 2010. Offshoring and wage inequality in developing countries. Journal of Economic Development 35, no. 3: 1-42.

Krishna, P., J.P. Poole, and M.Z. Senses. 2012. Trade, labor market frictions, and residual wage inequality across worker groups. American Economic Review: Papers \& Proceedings 102, no. 3: 417-23.

Kristjanpoller, W., and R. Contreras. 2017. Globalización y desigualdad: evidencia en América Latina. Lecturas de Economía 87: 9-33.

Kumar, U., and P. Mishra 2008. Trade liberalization and wage inequality: Evidence from India. Review of Development Economics 12, no. 2: 291-311.

Kuwayama, M. 2003. The comprehensiveness of Chilean free trade agreements. In Whither free trade agreements?: Proliferation, evaluation and multilateralization, ed. Jiro Okamoto, 175-215, Chiba, Japan: Institute of Developing Economies, Japan External Trade Organization.

Linarello, A. 2018. Direct and indirect effects of trade liberalization: Evidence from Chile. Journal of Development Economics 134: 160-75.

Levinsohn, J., and A. Petrin. 2003. Estimating production functions using inputs to control for unobservables. Review of Economic Studies 70, no. 2: 317-41.

Melitz, M.J. 2003. The impact of trade on intra-industry reallocations and aggregate industry productivity. Econometrica 71, no. 6: 1695-725. 
Macario, C. 2000. Chile: In search of new export drive. In Export growth in Latin America: Policies and performance, ed. C. Macario, M. Bonelli, A. T. Kate, and G. Niels, 48-72, Colorado: Lynne Rienner Publishers.

Messina, J., and J. Silva. 2019. Twenty years of wage inequality in Latin America. World Bank Economic Review (forthcoming).

Murakami, Y. 2014. Trade liberalization and skill premium in Chile. Revista México y la Cuenca del Pacífico, no. 6: 77-101.

Murakami, Y., and N. Hamaguchi. 2017. Peripherality, inequality, and economic development in Latin American countries, Discussion Paper Series DP2017-08, Research Institute for Economics \& Business Administration, Kobe University.

Murakami, Y. 2018. Globalization and income inequality in Latin America: A review of theoretical developments and recent evidence. RIEB Discussion Paper Series, DP2018-16, Research Institute for Economics \& Business Administration, Kobe University.

Murakami, Y., and T. Nomura. 2020. Expanding higher education and wage inequality in Chile. Journal of Economic Studies 47, no. 4 (forthcoming).

Namini, J.E., and R. Lopez. 2013. Factor price overshooting with trade liberalization: Theory and evidence. Scottish Journal of Political Economy 60, no. 2: 139-81.

Nataraj, S. 2011. The impact of trade liberalization on productivity: Evidence from India's formal and informal manufacturing sectors. Journal of International Economics 85: 292-301.

Parro, F., and L. Reyes. 2017. The rise and fall of income inequality in Chile, Latin American Economic Review 26, no. 3: 1-31.

Pavcnik, N. 2002. Trade liberalization, exit, and productivity improvement: Evidence from Chilean plants, Review of Economic Studies 69, no. 1: 245-76.

Pavcnik, N. 2017. The impact of trade on inequality in developing countries. Discussion paper series DP12331, Centre for Economic Policy Research, London.

Pavcnik, N., A. Blom, P.K. Goldberg, and N. Schady. 2004. Trade liberalization and industry wage structure: Evidence from Brazil. World Bank Economic Review 18 , no. 3: 319-44.

Paz, L.S. 2014. Trade liberalization and the inter-industry wage premia: the missing role of productivity. Applied Economics 46, no. 4: 408-19. 
Porto, G.G. 2006. Using survey data to assess the distributional effects of trade policy. Journal of International Economics 70: 140-60.

Revenga, A. 1997. Employment and wage effects of trade liberalization: The case of Mexican manufacturing. Journal of Labor Economics 15, no. 3, part. 2: S20-43. Rodriguez, F., and D. Rodrik. 2001. Trade policy and economic growth: A skeptic's guide to the cross-national evidence. NBER Macroeconomics Annual, 2000 15: 261-325.

Schor, A. 2004. Heterogeneous productivity response to tariff reduction. Evidence from Brazilian manufacturing firms. Journal of Development Economics 75: 373-96.

Schuschny, A., J. Durán, and C. de Miguel (2007), El modelo GTAP y las preferencias arancelarias en América Latina y el Caribe: reconciliando su año base con la evolución reciente de la agenda de liberalización regional, Santiago: CEPAL.

Stock, J. H., and M. Yogo. 2005. Testing for weak instruments in linear IV regression. In Identification and inference for econometric models: Essays in honor of Thomas Rothenberg, ed. D. W. K. Andrews and J. H. Stock, 80-108, Cambridge: Cambridge University Press.

Székely, M., and C. Sámano-Robles. 2014. Trade and income distribution in Latin America: Is there anything new to say? In Falling inequality in Latin America: Policy changes and lessons, ed. Giovanni A. Cornia, 234-250. Oxford, UK: Oxford University Press.

Suanes, M. 2016. Foreign direct investment and income inequality in Latin America: a sectoral analysis. CEPAL Review 118: 45-61.

Topalova, P., and A. Khandelwal. 2011. Trade Liberalization and Firm Productivity: The Case of India. Review of Economics and Statistics 93, no. 3: 995-1009.

Tybout, J., J. de Melo, and V. Corbo. 1991. The effects of trade technical efficiency: New evidence from Chile. Journal of International Economics 31: 231-50.

Valdés, A., and E. Jara. 2008. Chile. In Distortions to agricultural incentives in Latin America, ed. Kym Anderson and Alberto Valdés, 119-58, Washington DC: The World Bank.

Yeaple, S.R. 2005. A simple model of firm heterogeneity, international trade, and wages. Journal of International Economics 65: 1-20.

Zechner, C. 2002. Expanding NAFTA: Economic effects on Chile of free trade with the United States. Hamburg: Lit. 


\section{Appendix}

For the estimation of the plant-level TFP, we construct an unbalanced panel data for the 1995-2007 period. We estimate the production function separately for each three-digit industry. Note that, based on the Becerra's (2006) classification for effective tariff rates, we aggregate some industries with small observations at the three-digit level into one sector. Table A.1 reports the estimation results. The details of the variables employed are described below.

Output is measured by real sales. The deflator is the wholesale price index (originally, índice de precios al por mayor) [June $1992=1]$ in industrial sectors. The data for 1999 are sourced from Banco Central de Chile, ${ }^{1}$ while those for the 2000-2007 period are sourced from INE. ${ }^{2}$

Skilled and unskilled labor are measured by the total annual working hours of workers in the following occupational categories: skilled labor consists of owners, managers, specialized production workers, administrative personnel, and commissioned employees; unskilled labor consists of workers directly or indirectly involved in the production process and services workers.

Materials are the sum of the real domestic and imported materials. The deflators are the wholesale price index [June $1992=1$ ] of domestic and imported intermediate inputs, respectively. For 1999, we calculate them based on the weighted average of the wholesale price index, whose basket and weights are given by INE. For the 2000-2007 period, we source them directly from INE.

The energy inputs are the sum of the real net purchased value of electricity, other combustibles, and water. The deflator is the implicit deflator of electricity, gas,

\footnotetext{
${ }^{1}$ https://si3.bcentral.cl/Siete/secure/cuadros/home.aspx, accessed on February 8, 2018

${ }^{2}$ http://www.ine.cl/estadisticas/precios/ipm, accessed on February 8, 2018
} 
and water sectors [1992 = 1], sourced from the Statistical Yearbook for Latin America and the Caribbean of ECLAC. ${ }^{3}$ Service is measured by the sum of real expenditure on services such as advertising and promotion, commission payments, communications, insurance, legal and technical consulting, license and foreign technical assistance, maintenance and repair payments, rental and leasing payments, transport and storage, and other services. Payments to subcontracts are also included in this category. The deflator is the implicit deflator of service sectors [1992 = 1], sourced from the Statistical Yearbook for Latin America and the Caribbean of ECLAC.

Capital is proxied by the real values of tangible fixed assets, consisting of building, land, machinery and equipment, and vehicles. The deflators are the wholesale price index [June $1992=1$ ] of domestic capital goods. For the year 1999, we calculate them based on the weighted average of the wholesale price index, whose basket and weights are given by INE. For the 2000-2007 period, we source them directly from INE.

\footnotetext{
${ }^{3}$ http://interwp.cepal.org/anuario_estadistico/anuario_2015/en/index.asp, accessed on February 8, 2018
} 
Table A.1 Estimation results of the production function

\begin{tabular}{|c|c|c|c|c|c|c|c|c|}
\hline \multicolumn{9}{|c|}{ Dependent variable: $\log$ of output } \\
\hline & ISIC & 311,312 & 313,314 & 321 & 322 & 323,324 & 331 & 332 \\
\hline \multirow[t]{2}{*}{ Log of skilled labor } & & $0.0128 * *$ & 0.0342 & $0.0958 * * *$ & $0.0909 * * *$ & $0.0884 * * *$ & $0.0807 * * *$ & $0.0613 * * *$ \\
\hline & & $(0.00599)$ & $(0.0328)$ & $(0.0193)$ & $(0.0162)$ & $(0.0209)$ & $(0.0217)$ & $(0.0223)$ \\
\hline \multirow[t]{2}{*}{ Log of unskilled labor } & & $0.111 * * *$ & 0.0219 & $0.0989 * * *$ & $0.0888 * * *$ & $0.0418 * *$ & $0.147 * * *$ & $0.0411 * *$ \\
\hline & & $(0.00611)$ & $(0.0226)$ & $(0.0168)$ & $(0.0133)$ & $(0.0178)$ & $(0.0227)$ & $(0.0174)$ \\
\hline \multirow[t]{2}{*}{ Log of capital } & & $0.109 * * *$ & $0.112 * * *$ & $0.0636 * * *$ & $0.0429 * *$ & $0.0568 * * *$ & $0.0761 * * *$ & $0.0796 * * *$ \\
\hline & & $(0.0302)$ & $(0.0396)$ & $(0.0183)$ & $(0.0216)$ & $(0.0151)$ & $(0.0281)$ & $(0.0268)$ \\
\hline \multirow[t]{2}{*}{ Log of services } & & $0.0947 * * *$ & $0.127 * *$ & $0.212 * * *$ & $0.181 * * *$ & $0.145 * * *$ & $0.190 * * *$ & $0.182 * * *$ \\
\hline & & $(0.0291)$ & $(0.0603)$ & $(0.0192)$ & $(0.0289)$ & $(0.0269)$ & $(0.0439)$ & $(0.0335)$ \\
\hline \multirow[t]{2}{*}{ Log of materials } & & $0.551 * * *$ & $0.538 * * *$ & $0.373 * * *$ & $0.521 * * *$ & $0.607 * * *$ & $0.452 * * *$ & $0.593 * * *$ \\
\hline & & $(0.0560)$ & $(0.0792)$ & $(0.0353)$ & $(0.0449)$ & $(0.0211)$ & $(0.0335)$ & $(0.0433)$ \\
\hline \multirow[t]{2}{*}{ Log of electricity } & & $0.401 * * *$ & -0.0461 & -0.0270 & $0.188 * * *$ & $0.167 * * *$ & $0.381 * * *$ & $0.117 * * *$ \\
\hline & & $(0.0572)$ & $(0.0495)$ & $(0.0173)$ & $(0.0225)$ & $(0.0225)$ & $(0.0539)$ & $(0.0356)$ \\
\hline \multirow[t]{3}{*}{ Observations } & & 14,398 & 1,493 & 2,089 & 1,531 & 1,142 & 2,442 & 818 \\
\hline & \multicolumn{3}{|c|}{ Dependent variable: $\log$ of output } & & & & & \\
\hline & ISIC & 341 & 342 & 351 & 352 & $353,354,355$ & 356 & 361,362 \\
\hline \multirow[t]{2}{*}{ Log of skilled labor } & & $0.106 * * *$ & $0.0905^{* * *}$ & 0.0568 & $0.140 * * *$ & $0.0621 *$ & $0.0980 * * *$ & $0.102 * * *$ \\
\hline & & $(0.0199)$ & $(0.0217)$ & $(0.0480)$ & $(0.0256)$ & $(0.0353)$ & $(0.0184)$ & $(0.0321)$ \\
\hline \multirow[t]{2}{*}{ Log of unskilled labor } & & 0.0150 & $0.0478 * * *$ & 0.0398 & $0.0842 * * *$ & $0.0669 * * *$ & $0.0595 * * *$ & $0.238 * * *$ \\
\hline & & $(0.0220)$ & $(0.0154)$ & $(0.0308)$ & $(0.0205)$ & $(0.0231)$ & $(0.0130)$ & $(0.0411)$ \\
\hline \multirow[t]{2}{*}{ Log of capital } & & 0.0321 & 0.0108 & $0.148 * * *$ & 0.0251 & 0.0189 & $0.0606 * * *$ & $0.0971 * * *$ \\
\hline & & $(0.0289)$ & $(0.0214)$ & $(0.0414)$ & $(0.0224)$ & $(0.0292)$ & $(0.0209)$ & $(0.0334)$ \\
\hline \multirow[t]{2}{*}{ Log of services } & & $0.189 * * *$ & $0.139 * * *$ & $0.198 * * *$ & $0.151 * * *$ & $0.0875^{* *}$ & $0.132 * * *$ & $0.121 * *$ \\
\hline & & $(0.0468)$ & $(0.0301)$ & $(0.0411)$ & $(0.0308)$ & $(0.0371)$ & $(0.0254)$ & $(0.0517)$ \\
\hline \multirow[t]{2}{*}{ Log of materials } & & $0.468 * * *$ & $0.513 * * *$ & $0.454 * * *$ & $0.468 * * *$ & $0.648 * * *$ & $0.480 * * *$ & $0.450 * * *$ \\
\hline & & $(0.0635)$ & $(0.0531)$ & $(0.0600)$ & $(0.0327)$ & $(0.0319)$ & $(0.0435)$ & $(0.0486)$ \\
\hline \multirow[t]{2}{*}{ Log of electricity } & & $0.398 * * *$ & $-0.0805 * * *$ & $0.310 * * *$ & $0.0891 * * *$ & $0.406 * * *$ & $0.137 * * *$ & 0.0567 \\
\hline & & $(0.0632)$ & $(0.0277)$ & $(0.0430)$ & $(0.0245)$ & $(0.0246)$ & $(0.0284)$ & $(0.0467)$ \\
\hline Observations & & 875 & 1,682 & 524 & 1,374 & 645 & 2,126 & 437 \\
\hline
\end{tabular}




\begin{tabular}{|c|c|c|c|c|c|c|c|}
\hline \multicolumn{8}{|c|}{ Dependent variable: $\log$ of output } \\
\hline & ISIC & 369 & 371,372 & $381,383,385$ & 382 & 384 & 390 \\
\hline \multirow[t]{2}{*}{ Log of skilled labor } & & $0.0490 * *$ & 0.0204 & $0.135 * * *$ & $0.126 * * *$ & $0.161 * * *$ & $0.114 * * *$ \\
\hline & & $(0.0240)$ & $(0.0350)$ & $(0.0128)$ & $(0.0205)$ & $(0.0278)$ & $(0.0403)$ \\
\hline \multirow[t]{2}{*}{ Log of unskilled labor } & & $0.0411 * *$ & 0.0420 & $0.112 * * *$ & $0.0885^{* * *}$ & $0.0830 * * *$ & $0.183 * * *$ \\
\hline & & $(0.0197)$ & $(0.0258)$ & $(0.00992)$ & $(0.0135)$ & $(0.0201)$ & $(0.0415)$ \\
\hline \multirow[t]{2}{*}{ Log of capital } & & 0.00479 & 0.0321 & $0.0569 * * *$ & 0.0357 & 0.0571 & $0.0733 * *$ \\
\hline & & $(0.0176)$ & $(0.0444)$ & $(0.0146)$ & $(0.0251)$ & $(0.0428)$ & $(0.0318)$ \\
\hline \multirow[t]{2}{*}{ Log of services } & & $0.204 * * *$ & $0.249 * * *$ & $0.145^{* * * *}$ & $0.202 * * *$ & $0.251 * * *$ & $0.198 * * *$ \\
\hline & & $(0.0240)$ & $(0.0556)$ & $(0.0158)$ & $(0.0312)$ & $(0.0603)$ & $(0.0645)$ \\
\hline \multirow[t]{2}{*}{ Log of materials } & & $0.570 * * *$ & $0.432 * * *$ & $0.479 * * *$ & $0.396 * * *$ & $0.300 * *$ & $0.307 * * *$ \\
\hline & & $(0.0383)$ & $(0.0652)$ & $(0.0326)$ & $(0.0429)$ & $(0.127)$ & $(0.0494)$ \\
\hline \multirow[t]{2}{*}{ Log of electricity } & & $0.0667 *$ & $1.193 * * *$ & $0.0792 * * *$ & $0.289 * * *$ & -0.0575 & $0.527 * * *$ \\
\hline & & $(0.0349)$ & $(0.0766)$ & $(0.0197)$ & $(0.0339)$ & $(0.0509)$ & $(0.0377)$ \\
\hline Observations & & 1,077 & 989 & 6,345 & 1,665 & 758 & 439 \\
\hline
\end{tabular}

Note: $* * *, * *$, and $*$ indicate significance at $1 \%, 5 \%$, and $10 \%$ levels, respectively. Numbers in parentheses represent standard errors. 
Table 1. Descriptive statistics of individual and industry characteristics

\begin{tabular}{lrrrr}
\hline Variable & 2000 & 2003 & 2006 & 2009 \\
\hline Observations & 4,268 & 4,375 & 5,055 & 3,334 \\
Individual characteristics & & & & \\
Log hourly wage & 7.134 & 7.097 & 7.174 & 7.308 \\
Years of potential labor market experience & 19.079 & 19.557 & 19.815 & 21.529 \\
Head of the household & 0.710 & 0.640 & 0.588 & 0.617 \\
Married & 0.631 & 0.570 & 0.520 & 0.528 \\
Informal & 0.110 & 0.114 & 0.134 & 0.097 \\
Large-sized firm & 0.361 & 0.354 & 0.356 & 0.389 \\
Unskilled workers & 0.223 & 0.211 & 0.196 & 0.191 \\
Semiskilled workers & 0.560 & 0.600 & 0.606 & 0.619 \\
Skilled workers & 0.218 & 0.189 & 0.197 & 0.190 \\
Industry characteristics & & & & \\
Effective tariffs on final goods & & & & \\
Effective tariffs on intermediate goods & 0.078 & 0.034 & 0.022 & 0.016 \\
Share of foreign owned capital & 0.047 & 0.019 & 0.012 & 0.012 \\
Ratio of expenditure on licenses and foreign technical \\
assistance
\end{tabular}

Note: The number of observations is limited to the target profile described in Section 4 and additionally excludes any samples with missing values for the variables used.

Source: Author's calculations based on data from CASEN (2000, 2003, 2006, and 2009) for the individual characteristic, and data from ENIA (1999, 2002, 2005, and 2007), Becerra (2006), and WITS for the industry characteristics. 
Table 2. Estimation results of the impacts of trade liberalization on industry wage premiums

\begin{tabular}{|c|c|c|c|c|}
\hline & (1) & (2) & (3) & (4) \\
\hline Log output tariff & $\begin{array}{c}-0.134 * * * \\
(0.040)\end{array}$ & $\begin{array}{c}-0.134 * * * \\
(0.044)\end{array}$ & $\begin{array}{c}-0.130 * * * \\
(0.043)\end{array}$ & $\begin{array}{c}-0.116^{* *} \\
(0.044)\end{array}$ \\
\hline Log input tariff & & $\begin{array}{l}-0.001 \\
(0.055)\end{array}$ & & \\
\hline FDI & & & $\begin{array}{c}0.124 \\
(0.081)\end{array}$ & $\begin{array}{c}0.122 \\
(0.080)\end{array}$ \\
\hline Foreign technology & & & $\begin{array}{c}12.731^{* *} \\
(5.687)\end{array}$ & $\begin{array}{c}12.807 * * \\
(5.690)\end{array}$ \\
\hline $\begin{array}{l}\text { Log output tariff } \times \text { large-sized } \\
\text { firms }\end{array}$ & & & & $\begin{array}{l}-0.030 \\
(0.026)\end{array}$ \\
\hline Semiskilled & $\begin{array}{c}0.279 * * * \\
(0.036)\end{array}$ & $\begin{array}{c}0.280 * * * \\
(0.036)\end{array}$ & $\begin{array}{c}0.275^{* * *} \\
(0.035)\end{array}$ & $\begin{array}{c}0.278 * * * \\
(0.037)\end{array}$ \\
\hline Semiskilled $\times$ year 2003 & $\begin{array}{l}-0.023 \\
(0.036)\end{array}$ & $\begin{array}{l}-0.023 \\
(0.036)\end{array}$ & $\begin{array}{l}-0.018 \\
(0.035)\end{array}$ & $\begin{array}{l}-0.021 \\
(0.037)\end{array}$ \\
\hline Semiskilled $\times$ year 2006 & $\begin{array}{l}-0.029 \\
(0.036)\end{array}$ & $\begin{array}{l}-0.029 \\
(0.036)\end{array}$ & $\begin{array}{l}-0.022 \\
(0.035)\end{array}$ & $\begin{array}{l}-0.027 \\
(0.036)\end{array}$ \\
\hline Semiskilled $\times$ year 2009 & $\begin{array}{l}-0.084 * \\
(0.048)\end{array}$ & $\begin{array}{l}-0.084 * \\
(0.049)\end{array}$ & $\begin{array}{l}-0.081 \\
(0.048)\end{array}$ & $\begin{array}{l}-0.089^{*} \\
(0.051)\end{array}$ \\
\hline Skilled & $\begin{array}{c}1.153 * * * \\
(0.084)\end{array}$ & $\begin{array}{c}1.153 * * * \\
(0.084)\end{array}$ & $\begin{array}{c}1.141 * * * \\
(0.080)\end{array}$ & $\begin{array}{c}1.149 * * * \\
(0.080)\end{array}$ \\
\hline Skilled $\times$ year 2003 & $\begin{array}{l}-0.150 \\
(0.092)\end{array}$ & $\begin{array}{l}-0.150 \\
(0.091)\end{array}$ & $\begin{array}{l}-0.140 \\
(0.092)\end{array}$ & $\begin{array}{l}-0.148 \\
(0.091)\end{array}$ \\
\hline Skilled $\times$ year 2006 & $\begin{array}{c}-0.237 * * \\
(0.097)\end{array}$ & $\begin{array}{c}-0.237 * * \\
(0.097)\end{array}$ & $\begin{array}{c}-0.219 * * \\
(0.091)\end{array}$ & $\begin{array}{c}-0.231 * * \\
(0.089)\end{array}$ \\
\hline Skilled $\times$ year 2009 & $\begin{array}{c}-0.378 * * * \\
(0.086)\end{array}$ & $\begin{array}{c}-0.379 * * * \\
(0.086)\end{array}$ & $\begin{array}{c}-0.375^{* * *} \\
(0.083)\end{array}$ & $\begin{array}{c}-0.391 * * * \\
(0.080)\end{array}$ \\
\hline Large-sized firms & $\begin{array}{c}0.161 * * * \\
(0.022)\end{array}$ & $\begin{array}{c}0.161 * * * \\
(0.022)\end{array}$ & $\begin{array}{c}0.159 * * * \\
(0.023)\end{array}$ & $\begin{array}{c}0.055 \\
(0.107)\end{array}$ \\
\hline Constant & $\begin{array}{c}5.824 * * * \\
(0.138)\end{array}$ & $\begin{array}{c}5.821 * * * \\
(0.188)\end{array}$ & $\begin{array}{c}5.796 * * * \\
(0.137)\end{array}$ & $\begin{array}{c}5.833 * * * \\
(0.146)\end{array}$ \\
\hline $\begin{array}{l}\text { Industry effects } \\
\text { Year effects }\end{array}$ & $\begin{array}{l}\text { yes } \\
\text { yes }\end{array}$ & $\begin{array}{l}\text { yes } \\
\text { yes }\end{array}$ & $\begin{array}{l}\text { yes } \\
\text { yes }\end{array}$ & $\begin{array}{l}\text { yes } \\
\text { yes }\end{array}$ \\
\hline Observations & 17,032 & 17,032 & 17,032 & 17,032 \\
\hline$R$-squared & 0.426 & 0.426 & 0.428 & 0.429 \\
\hline
\end{tabular}

Note: $* *$, and $*$ indicate significance at $1 \%, 5 \%$, and $10 \%$ levels, respectively. Numbers in parentheses represent robust-standard errors clustered at the three-digit industry level. Years of potential labor market experience and its squared term including their interactions with year effects, demographic dummies, informal dummy, and region dummies are also included. 
Table 3. Estimation results of impacts of trade liberalization on industry skill premiums

\begin{tabular}{|c|c|c|c|c|}
\hline & $(1)$ & $(2)$ & (3) & (4) \\
\hline \multirow[t]{2}{*}{ Log output tariff } & -0.039 & -0.045 & -0.033 & -0.035 \\
\hline & $(0.035)$ & $(0.040)$ & $(0.037)$ & $(0.040)$ \\
\hline \multirow[t]{2}{*}{ Log output tariff $\times$ semiskilled } & $-0.097 * *$ & -0.070 & $-0.098 * *$ & $-0.089 *$ \\
\hline & $(0.045)$ & $(0.047)$ & $(0.047)$ & $(0.048)$ \\
\hline \multirow[t]{2}{*}{ Log output tariff $\times$ skilled } & $-0.186 * * *$ & $-0.220 * *$ & $-0.167 * *$ & $-0.134 *$ \\
\hline & $(0.067)$ & $(0.102)$ & $(0.067)$ & $(0.066)$ \\
\hline \multirow[t]{2}{*}{ Log input tariff } & & 0.011 & & \\
\hline & & $(0.060)$ & & \\
\hline \multirow[t]{2}{*}{ Log input tariff $\times$ semiskilled } & & -0.056 & & \\
\hline & & $(0.040)$ & & \\
\hline \multirow[t]{2}{*}{ Log input tariff $\times$ skilled } & & 0.075 & & \\
\hline & & $(0.134)$ & & \\
\hline \multirow[t]{2}{*}{ FDI } & & & -0.017 & -0.008 \\
\hline & & & $(0.109)$ & $(0.111)$ \\
\hline \multirow[t]{2}{*}{ FDI $\times$ semiskilled } & & & 0.049 & 0.043 \\
\hline & & & $(0.096)$ & $(0.099)$ \\
\hline \multirow[t]{2}{*}{ FDI $\times$ skilled } & & & $0.466 * *$ & $0.444 * *$ \\
\hline & & & $(0.178)$ & $(0.179)$ \\
\hline \multirow[t]{2}{*}{ Foreign technology } & & & 13.402 & 13.140 \\
\hline & & & $(9.415)$ & $(9.520)$ \\
\hline \multirow[t]{2}{*}{ Foreign technology $\times$ semiskilled } & & & -6.367 & -6.111 \\
\hline & & & $(7.420)$ & $(7.641)$ \\
\hline \multirow[t]{2}{*}{ Foreign technology $\times$ skilled } & & & 6.123 & 6.709 \\
\hline & & & $(13.913)$ & $(14.141)$ \\
\hline \multirow[t]{2}{*}{ Log output tariff $\times$ large-sized firms } & & & & -0.005 \\
\hline & & & & $(0.030)$ \\
\hline \multirow[t]{2}{*}{ Log output tariff $\times$ semiskilled $\times$ large-sized firms } & & & & $-0.013^{*}$ \\
\hline & & & & $(0.007)$ \\
\hline \multirow[t]{2}{*}{ Log output tariff $\times$ skilled $\times$ large-sized firms } & & & & $-0.037 * *$ \\
\hline & & & & $(0.015)$ \\
\hline \multirow[t]{2}{*}{ Large-sized firms } & $0.160 * * *$ & $0.160 * * *$ & $0.158 * * *$ & 0.084 \\
\hline & $(0.022)$ & $(0.022)$ & $(0.022)$ & $(0.109)$ \\
\hline \multirow[t]{2}{*}{ Constant } & $6.053 * * *$ & $6.073 * * *$ & $6.053 * * *$ & $6.062 * * *$ \\
\hline & $(0.128)$ & $(0.177)$ & $(0.129)$ & $(0.138)$ \\
\hline Industry effects & yes & yes & yes & yes \\
\hline Year effects & yes & yes & yes & yes \\
\hline Observations & 17,032 & 17,032 & 17,032 & 17,032 \\
\hline$R$-squared & 0.427 & 0.427 & 0.432 & 0.433 \\
\hline
\end{tabular}

Note: $* * * * *$, and $*$ indicate significance at $1 \%, 5 \%$, and $10 \%$ levels, respectively. Numbers in parentheses represent robust-standard errors clustered at the three-digit industry level. Skilled dummies and their interactions with year effects, years of potential labor market experience and its squared term, including their interactions with year effects, demographic dummies, informal dummy, and region dummies are also included. 
Table 4. Estimation results of the impacts of trade liberalization on industry wage premiums with industry-level TFP

\begin{tabular}{|c|c|c|c|c|}
\hline & $(1)$ & $(2)$ & (3) & $(4)$ \\
\hline \multirow[t]{2}{*}{ TFP } & 0.030 & 0.030 & $0.032 * *$ & $0.034 * *$ \\
\hline & $(0.019)$ & $(0.019)$ & $(0.015)$ & $(0.015)$ \\
\hline \multirow[t]{2}{*}{ Log output tariff } & $-0.131 * * *$ & $-0.130 * * *$ & $-0.126^{* * *}$ & $-0.111^{* *}$ \\
\hline & $(0.040)$ & $(0.045)$ & $(0.042)$ & $(0.044)$ \\
\hline \multirow[t]{2}{*}{ Log input tariff } & & -0.004 & & \\
\hline & & $(0.051)$ & & \\
\hline \multirow[t]{2}{*}{ FDI } & & & 0.135 & 0.133 \\
\hline & & & $(0.082)$ & $(0.082)$ \\
\hline \multirow[t]{2}{*}{ Foreign technology } & & & $13.015^{* *}$ & $13.089 * *$ \\
\hline & & & $(5.739)$ & $(5.759)$ \\
\hline \multirow[t]{2}{*}{ Log output tariff $\times$ large-sized firms } & & & & -0.033 \\
\hline & & & & $(0.026)$ \\
\hline \multirow[t]{2}{*}{ Large-sized firms } & $0.160 * * *$ & $0.160 * * *$ & $0.158 * * *$ & 0.043 \\
\hline & $(0.022)$ & $(0.022)$ & $(0.023)$ & $(0.109)$ \\
\hline \multirow[t]{2}{*}{ Constant } & $5.767 * * *$ & $5.759 * * *$ & $5.732 * * *$ & $5.771 * * *$ \\
\hline & $(0.130)$ & $(0.174)$ & $(0.132)$ & $(0.141)$ \\
\hline Industry effects & yes & yes & yes & yes \\
\hline Year effects & yes & yes & yes & yes \\
\hline Observations & 17,015 & 17,015 & 17,015 & 17,015 \\
\hline R-squared & 0.426 & 0.426 & 0.429 & 0.429 \\
\hline
\end{tabular}

Note: $* * *, * *$, and $*$ indicate significance at $1 \%, 5 \%$, and $10 \%$ levels, respectively. Numbers in parentheses represent robust-standard errors clustered at the three-digit industry level. Skilled dummies and their interactions with year effects, years of potential labor market experience and its squared term, including their interactions with year effects, demographic dummies, informal dummy, and region dummies are also included. The smaller number of observations than the estimation without industry-level TFP is due to the missing samples of ISIC 353 in ENIA 2005. 
Table 5. Estimation results of the impacts of trade liberalization on industry skill premiums with industry-level TFP

\begin{tabular}{|c|c|c|c|c|}
\hline & $(1)$ & $(2)$ & (3) & (4) \\
\hline \multirow[t]{2}{*}{ TFP } & $0.032 *$ & $0.032 *$ & $0.031 * *$ & $0.032 * *$ \\
\hline & $(0.018)$ & $(0.018)$ & $(0.015)$ & $(0.015)$ \\
\hline \multirow[t]{2}{*}{ Log output tariff } & -0.033 & -0.040 & -0.027 & -0.028 \\
\hline & $(0.035)$ & $(0.042)$ & $(0.038)$ & $(0.041)$ \\
\hline \multirow[t]{2}{*}{ Log output tariff $\times$ semiskilled } & $-0.098 * *$ & -0.070 & $-0.099 * *$ & $-0.089^{*}$ \\
\hline & $(0.044)$ & $(0.046)$ & $(0.047)$ & $(0.047)$ \\
\hline \multirow[t]{2}{*}{ Log output tariff $\times$ skilled } & $-0.193 * * *$ & $-0.222 * *$ & $-0.176^{* *}$ & $-0.142 * *$ \\
\hline & $(0.065)$ & $(0.103)$ & $(0.064)$ & $(0.063)$ \\
\hline \multirow[t]{2}{*}{ Log input tariff } & & 0.012 & & \\
\hline & & $(0.057)$ & & \\
\hline \multirow[t]{2}{*}{ Log input tariff $\times$ semiskilled } & & -0.058 & & \\
\hline & & $(0.040)$ & & \\
\hline \multirow[t]{2}{*}{ Log input tariff $\times$ skilled } & & 0.064 & & \\
\hline & & $(0.136)$ & & \\
\hline \multirow{2}{*}{ FDI } & & & -0.002 & 0.007 \\
\hline & & & (0.109) & (0.111) \\
\hline \multirow[t]{2}{*}{ FDI $\times$ semiskilled } & & & 0.044 & 0.036 \\
\hline & & & $(0.096)$ & $(0.099)$ \\
\hline \multirow[t]{2}{*}{ FDI $\times$ skilled } & & & $0.464 * *$ & $0.442 * *$ \\
\hline & & & $(0.178)$ & $(0.180)$ \\
\hline \multirow[t]{2}{*}{ Foreign technology } & & & 13.719 & 13.421 \\
\hline & & & $(9.196)$ & $(9.336)$ \\
\hline \multirow[t]{2}{*}{ Foreign technology $\times$ semiskilled } & & & -6.228 & -5.953 \\
\hline & & & $(7.405)$ & $(7.639)$ \\
\hline \multirow[t]{2}{*}{ Foreign technology $\times$ skilled } & & & 6.004 & 6.542 \\
\hline & & & $(13.830)$ & $(14.045)$ \\
\hline \multirow[t]{2}{*}{ Log output tariff $\times$ large-sized firms } & & & & -0.007 \\
\hline & & & & $(0.030)$ \\
\hline \multicolumn{5}{|c|}{$\begin{array}{l}\text { Log output tariff } \times \text { semiskilled } \times \text { large-sized } \\
\text { firms }\end{array}$} \\
\hline firms & & & & $\begin{array}{c}-0.014 * * \\
(0.007)\end{array}$ \\
\hline \multicolumn{5}{|l|}{ Log output tariff $\times$ skilled $\times$ large-sized } \\
\hline firms & & & & $\begin{array}{c}-0.037 * * \\
(0.015)\end{array}$ \\
\hline \multirow[t]{2}{*}{ Large-sized firms } & $0.160 * * *$ & $0.160 * * *$ & $0.158 * * *$ & 0.075 \\
\hline & $(0.022)$ & $(0.022)$ & $(0.023)$ & $(0.111)$ \\
\hline \multirow[t]{2}{*}{ Constant } & $5.998 * * *$ & $6.019 * * *$ & $5.995 * * *$ & $6.004 * * *$ \\
\hline & $(0.126)$ & $(0.173)$ & $(0.128)$ & $(0.137)$ \\
\hline Industry effects & yes & yes & yes & yes \\
\hline Year effects & yes & yes & yes & yes \\
\hline Observations & 17,015 & 17,015 & 17,015 & 17,015 \\
\hline R-squared & 0.427 & 0.427 & 0.433 & 0.434 \\
\hline
\end{tabular}

Note: $* * *, * *$, and $*$ indicate significance at $1 \%, 5 \%$, and $10 \%$ levels, respectively. Numbers in parentheses represent robust-standard errors clustered at the three-digit industry level. Skilled dummies and their interactions with year effects, years of potential labor market experience and its squared term, including their interactions with year effects, demographic dummies, informal dummy, and region dummies are also included. 
Table 6. Estimation results of the impacts of trade liberalization on industry wage premiums and industry skill premiums using instrumental variable

\begin{tabular}{|c|c|c|c|c|c|c|}
\hline & (1) & (2) & (3) & (4) & (5) & (6) \\
\hline Technique & 2 SLS & 2 SLS & 2 SLS & 2 SLS & 2 SLS & 2 SLS \\
\hline TFP & $\begin{array}{c}0.015 \\
(0.023)\end{array}$ & $\begin{array}{c}0.018 \\
(0.016)\end{array}$ & $\begin{array}{c}0.019 \\
(0.016)\end{array}$ & $\begin{array}{c}0.016 \\
(0.023)\end{array}$ & $\begin{array}{c}0.016 \\
(0.016)\end{array}$ & $\begin{array}{c}0.016 \\
(0.017)\end{array}$ \\
\hline Log output tariff & $\begin{array}{c}-0.450 * * * \\
(0.112)\end{array}$ & $\begin{array}{c}-0.412 * * * \\
(0.084)\end{array}$ & $\begin{array}{c}-0.405^{* * *} \\
(0.086)\end{array}$ & $\begin{array}{c}-0.262 * * \\
(0.114)\end{array}$ & $\begin{array}{c}-0.222 * * \\
(0.091)\end{array}$ & $\begin{array}{c}-0.232 * * * \\
(0.089)\end{array}$ \\
\hline Log output tariff $\times$ semiskilled & & & & $\begin{array}{c}-0.232 * * * \\
(0.053)\end{array}$ & $\begin{array}{c}-0.251 * * * \\
(0.057)\end{array}$ & $\begin{array}{c}-0.246 * * * \\
(0.055)\end{array}$ \\
\hline Log output tariff $\times$ skilled & & & & $\begin{array}{c}-0.204 * * \\
(0.097)\end{array}$ & $\begin{array}{c}-0.217 * * \\
(0.098)\end{array}$ & $\begin{array}{c}-0.207 * * \\
(0.099)\end{array}$ \\
\hline FDI & & $\begin{array}{c}0.101 \\
(0.073)\end{array}$ & $\begin{array}{c}0.099 \\
(0.072)\end{array}$ & & $\begin{array}{l}-0.020 \\
(0.096)\end{array}$ & $\begin{array}{l}-0.012 \\
(0.097)\end{array}$ \\
\hline FDI $\times$ semiskilled & & & & & $\begin{array}{c}0.027 \\
(0.101)\end{array}$ & $\begin{array}{c}0.021 \\
(0.104)\end{array}$ \\
\hline FDI $\times$ skilled & & & & & $\begin{array}{c}0.434 * * * \\
(0.167)\end{array}$ & $\begin{array}{c}0.412 * * \\
(0.168)\end{array}$ \\
\hline Foreign technology & & $\begin{array}{l}13.388 * * * \\
(4.660)\end{array}$ & $\begin{array}{l}13.468 * * * \\
(4.669)\end{array}$ & & $\begin{array}{c}15.603 * * \\
(6.910)\end{array}$ & $\begin{array}{c}15.401 * * \\
(6.969)\end{array}$ \\
\hline $\begin{array}{l}\text { Foreign technology } x \\
\text { semiskilled }\end{array}$ & & & & & $\begin{array}{l}-8.064 \\
(8.275)\end{array}$ & $\begin{array}{l}-7.861 \\
(8.449)\end{array}$ \\
\hline Foreign technology $\times$ skilled & & & & & $\begin{array}{c}4.051 \\
(13.132)\end{array}$ & $\begin{array}{c}4.402 \\
(13.309)\end{array}$ \\
\hline $\begin{array}{l}\text { Log output tariff } \times \text { large-sized } \\
\text { firms }\end{array}$ & & & $\begin{array}{l}-0.031 \\
(0.035)\end{array}$ & & & $\begin{array}{c}0.001 \\
(0.045)\end{array}$ \\
\hline $\begin{array}{l}\text { Log output tariff } \times \text { semiskilled } \\
\times \text { large-sized firms }\end{array}$ & & & & & & $\begin{array}{l}-0.012 * \\
(0.007)\end{array}$ \\
\hline $\begin{array}{l}\text { Log output tariff } \times \text { skilled } \times \\
\text { large-sized firms }\end{array}$ & & & & & & $\begin{array}{c}-0.034 * * \\
(0.016)\end{array}$ \\
\hline Large-sized firms & $\begin{array}{c}0.148 * * * \\
(0.022)\end{array}$ & $\begin{array}{c}0.148 * * * \\
(0.023)\end{array}$ & $\begin{array}{c}0.039 \\
(0.138)\end{array}$ & $\begin{array}{c}0.149 * * * \\
(0.023)\end{array}$ & $\begin{array}{c}0.147 * * * \\
(0.023)\end{array}$ & $\begin{array}{c}0.099 \\
(0.166)\end{array}$ \\
\hline Constant & $\begin{array}{c}5.026^{* * * *} \\
(0.240)\end{array}$ & $\begin{array}{c}5.077 * * * \\
(0.183)\end{array}$ & $\begin{array}{c}5.096 * * * \\
(0.187)\end{array}$ & $\begin{array}{c}5.486 * * * \\
(0.251)\end{array}$ & $\begin{array}{c}5.568 * * * \\
(0.206)\end{array}$ & $\begin{array}{c}5.554 * * * \\
(0.201)\end{array}$ \\
\hline $\begin{array}{l}\text { Industry effects } \\
\text { Year effects }\end{array}$ & $\begin{array}{l}\text { yes } \\
\text { yes }\end{array}$ & $\begin{array}{l}\text { yes } \\
\text { yes }\end{array}$ & $\begin{array}{l}\text { yes } \\
\text { yes }\end{array}$ & $\begin{array}{l}\text { yes } \\
\text { yes }\end{array}$ & $\begin{array}{l}\text { yes } \\
\text { yes }\end{array}$ & $\begin{array}{l}\text { yes } \\
\text { yes }\end{array}$ \\
\hline $\begin{array}{l}\text { Kleibergen-Paap rank F statistic } \\
\text { Stock-Yogo weak ID test }\end{array}$ & 33.97 & 33.99 & 17.14 & 11.37 & 11.39 & 5.78 \\
\hline critical value at $10 \%$ & 16.38 & 16.38 & 7.03 & & & \\
\hline Durbin-Wu-Hausman test & $\begin{array}{l}10.33 * * * \\
{[0.0033]}\end{array}$ & $\begin{array}{l}10.39 * * * \\
{[0.0032]}\end{array}$ & $\begin{array}{l}5.51 * * * \\
{[0.0096]}\end{array}$ & $\begin{array}{l}7.96 * * * \\
{[0.0005]}\end{array}$ & $\begin{array}{l}8.42 * * * \\
{[0.0004]}\end{array}$ & $\begin{array}{l}6.76 * * * \\
{[0.0002]}\end{array}$ \\
\hline Observations & 17,015 & 17,015 & 17,015 & 17,015 & 17,015 & 17,015 \\
\hline R-squared & 0.412 & 0.417 & 0.417 & 0.413 & 0.420 & 0.420 \\
\hline
\end{tabular}

Note: $* * *, * *$, and $*$ indicate significance at $1 \%, 5 \%$, and $10 \%$ levels, respectively. Numbers in parentheses represent robust-standard errors clustered at the three-digit industry level. Numbers in brackets represent $p$-values. 2SLS indicates that the two-stage least squares estimation is used. The Stock-Yogo critical values are available up to a maximum of two endogenous regressors (see Table 5.2 in Stock and Yogo 2005, 101). Skilled dummies and their interactions with year effects, years of potential labor market experience and its squared term, including their interactions with year effects, demographic dummies, informal dummy, and region dummies are also included. 


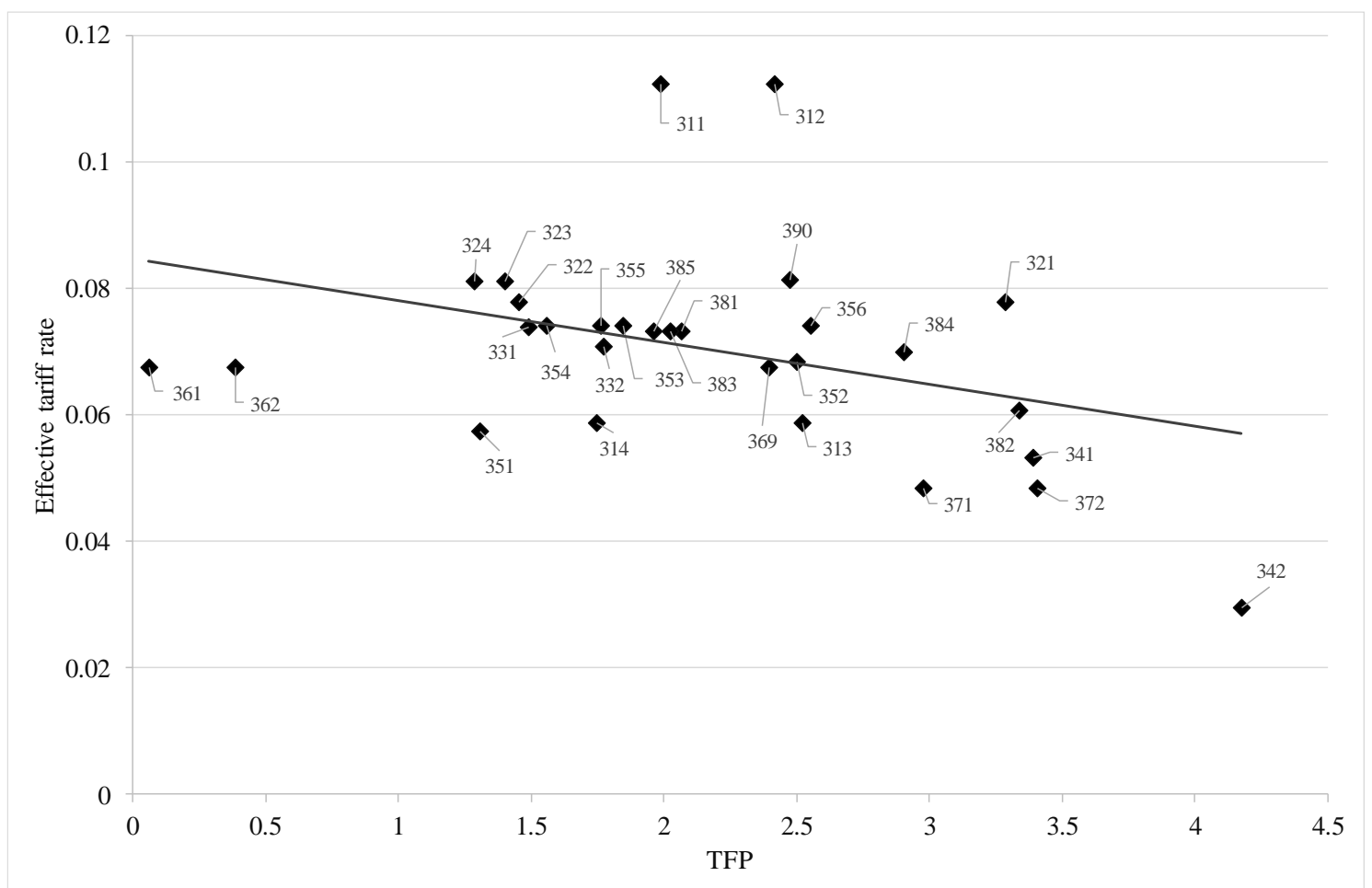

Figure 1.

Source: Author's elaboration.

Note: The numbers show three-digit international standard industrial classification (ISIC Rev.2) codes. 


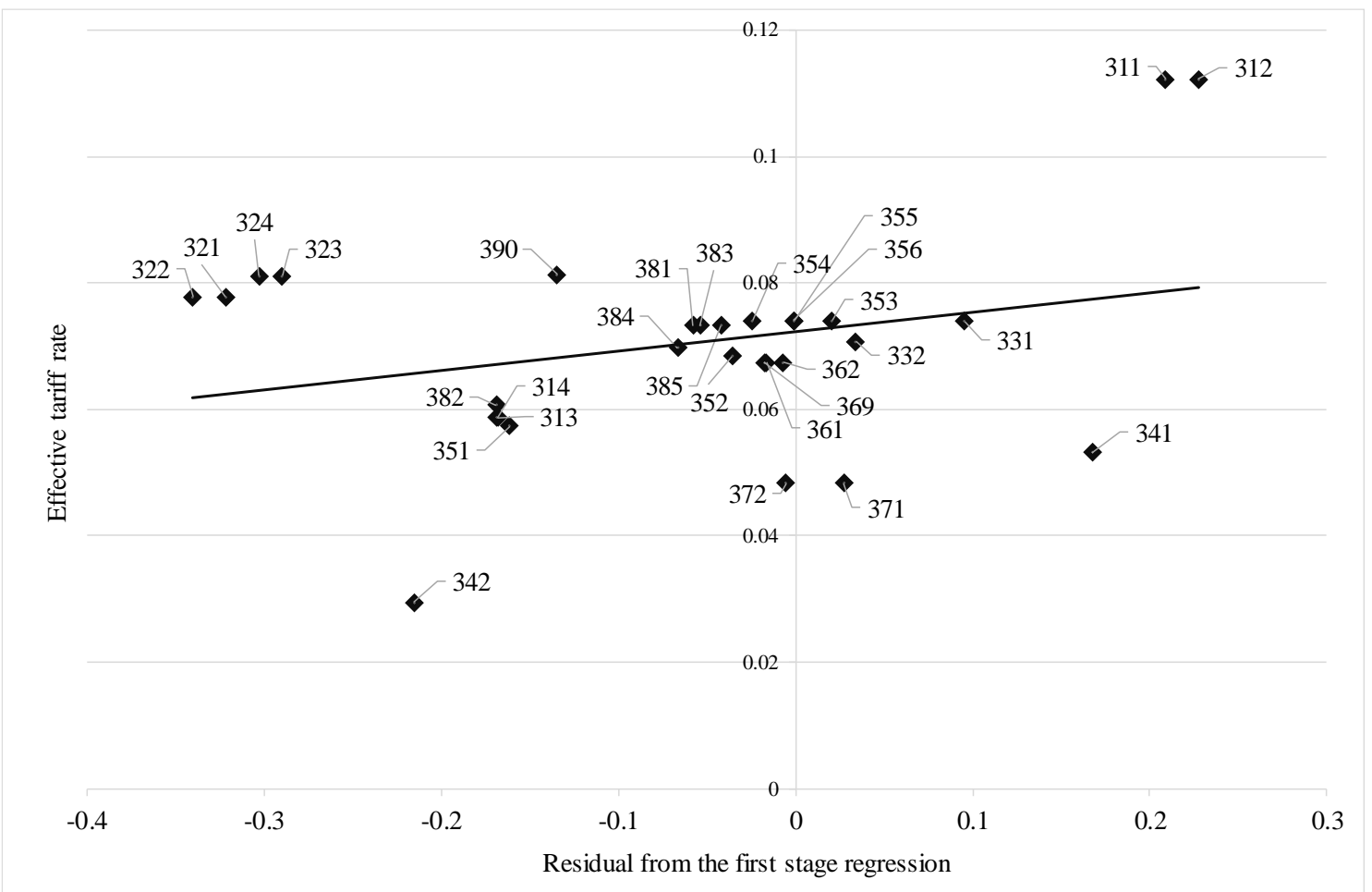

Figure 2.

Source: Author's elaboration.

Note: The numbers show three-digit international standard industrial classification (ISIC Rev.2) codes. 


\section{Figure Captions}

Figure 1. Effective tariff rate and TFP in 2000

Figure 2. Effective tariff rate and the residual from the first stage regression in 2000 